3,

Whot

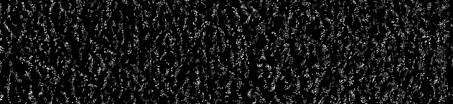
$1,1,1$ 


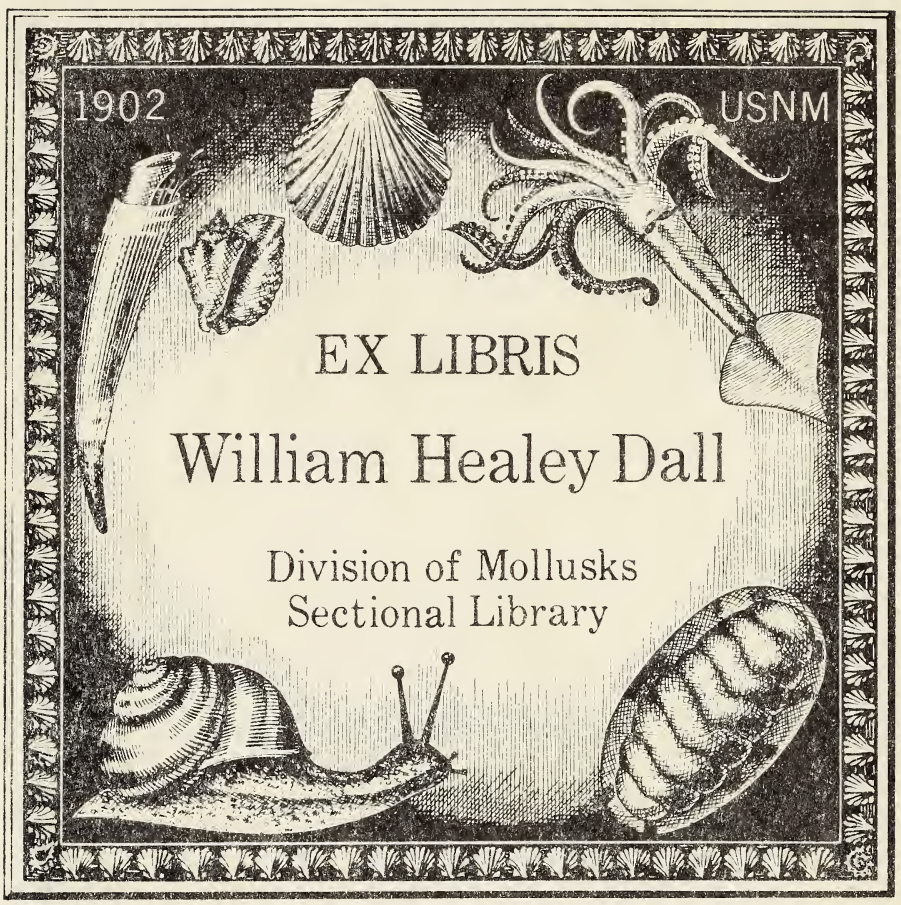


I-Conrad

WLIMM H. DALE SECTONAL LBRARY DWSON OE NOLUSRS 



I conens 



\section{N E W \\ ffregh ขeater Ebells \\ OF THE}

UNITED STATES,

WITH LITHOGRAPHIC ILLUSTRATIONS,

AND

A MONOGRAPH

OF THE

GENUS ANCULOTUS OF SAY;

ALSO

A SYNOPSIS OF THE AMERICAN NAIADES.

BY T. A. CONRAD,

Member of the Acad. of Natural Sciences of Philadelphia.

P H I L A D E L P H I A :

Judah Dobson, 108 Chesnet Street.

E. G. DORSEY, PRINTER.

May 3, 1834. 

N E W

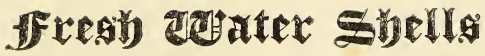

OF THE

UNITED STATES,

WITH COLOURED ILLUSTRATIONS,

AND

A MONOGRAPH

OF THE

GENUS ANCULOTUS OF SAY;

ALSO

A SYNOPSIS OF THE AMERICAN NAIADES.

BY T. A. CONRAD,

Hember of the Acad. of Natural Sciences of Philadclphia.

P H I L A D E L P H I A :

Judah Dobson, 108 Chesnut Street.

E. G. DOREEY, PRINTER.

1834. 

CHARLES A. POULSON, Es̃.

Member of the Academy of Natural Sciences, ঞc.

Dear Sir,-I take the liberty to dedicate this volume to you, whose liberality has afforded the friends of science the use of a library, richer in works on Conchology than any other in the United. States; and of a collection of shells almost unrivalled by any private cabinet. It is therefore with great pleasure that I embrace this occasion to acknowledge my obligations to you; and I sincerely wish that so pleasing and instructive a study as that of Natural Science may long continue to amuse your leisure hours.

I am, dear sir,

Your obedient servant,

T. A. Conrad.

Philadelphia, April 4, 1834. 



\section{INTRODUCTION.}

WHLST residing in the mansion of my kind and hospitable friend, Judge TAIT, of Claiborne, Alabama, where I was employed in collecting the organic remains of the vicinity, I occasionally made excursions up or down the Alabama river, for the purpose of procuring fresh water shells. I have succeeded in obtaining some species which I believe to be new, and hope to fix by accurate delineations and descriptions. A careful search for all the species inhabiting the Black Warrior at Erie, and again in Jefferson county, north of Elyton, together with researches in the streams of the Tennessee Valley, have furnished other species, several of which I presume to be undescribed. If in any instance I have thus introduced a shell of which a published description already exists, I will cheerfully resign the name I may have given it and "render unto Cæsar the things which are Cæsar's;" but where a claim is made upon such shells, merely because the descriptions may have been read to the members of some institution, I 
shall certainly not feel myself compelled to make any such restitution. The day of publication can alone decide a question of this kind, else a naturalist might describe fifty species at random, read them at a meeting of some scientific institution, and then cull out at his leisure a half dozen new ones, and claim them as his own six years afterwards, although perhaps they had been published. under other names, five years before his descriptions appeared. Other reasons could be given, but it is unnecessary to multiply them in so plain a case. I will, however, observe, that a naturalist lately read descriptions of two hundred new species, and when his descriptions were published, they amounted to two hundred and fifly-how can any one distinguish the interpolations?

The great variety and beauty of the fresh water shells of this country are truly surprising. Whilst the streams of Europe contain very few species, not remarkable for elegance of colour or variety of form, the rivers of Ohio, Kentucky, Tennessee, Alabana, \&c. contain at least one hundred species of almost every imaginable shape. Many of these are richly coloured and ornamented with rays, tubercles and undulations, and some equal in lustre the habitation of the oriental pearl. To these beautiful and multiform shells, the few less ornamental species of the 
Atlantic rivers form a striking contrast; and it has been a desideratum to discover where the line of demarcation has been drawn by nature in the southern states, between these two distinct races of shells, and to fix with certainty the geographical limits of the different species. The latter can only be effected by years of patient observation; but by contributing such facts connected with the subject as may come under our notice, we prepare the way for those who may in future pursue the interesting inquiry with more energy and zeal.

It appears that the great lakes contain some of those species of Naiades, which inhabit the Ohio, and the Unio cardium, RAF. U. inflatus, BARNES, and U. ala$t u s$, SAY, have been found in Lake Champlain, y et none of the tide waters of the Atlantic states contain either of these species, nor any other of those denominated "western shells." The Unio cariosus of $\mathrm{S}_{\mathrm{AY}}$ is the only acknowledged species common to all the waters of the United States, although Alasmodonta marginata of the Schuylkill is very analogous to a species in the Ohio. Mr. SAY, however, who is best qualified to decide the point, thinks they are distinct. It is remarkable that our eastern waters do not furnish a single tuberculated, alated or plicated bivalve, and the species are thin compared with the greater number of those in the western waters. Yet it is 
equally remarkable that the latter also contain the thinnest and most fragile as well as the most ponderous species.

During a recent journey through Georgia and Alabama, I was enabled to learn the western limits of that class of shells of which Unio purpureus of SAY may be considered the most characteristic. They occur in the Savannah, Oconee and Ocmulgee, but there they terminate, as Flint river, the first tributary of the Gulf of Mexico, which I crossed in my route, furnishes plicated shells and species identical with some inhabiting the Ohio. I have not examined any of the rivers intermediate to the Flint and Ocmulgee, but as these two are only thirty miles distant from each other, and are not divided by a range of mountains, I think the fact that the Ocmulgee contains the "eastern" and the Flint the "western" species, substantiates the theory I have for years indulged, that the shells of the Atlantic streams differ in their general character from those of all the waters which flow into the Gulf of Mexico. I must observe, however, that a shell which I believe to be Unio purpureus, occurs in Flint river, in company with the ponderous and plicated shells, but west of this I never observed the species. A variety of $U$. declivis, $\mathrm{SAY}_{\mathrm{A}}$, was found in East Florida by $\mathrm{DR}$. Blanding, and $U$. parvus, Barnes, it is said, also 
occurs there. How many more of the western species inhabit the Atlantic rivers of East Florida, is an interesting problem which some future observer must solve.

The propriety of separating the Naiades into so great a number of species, especially as they have been divided by RAFINESQUE and LEa, has often been doubted by conchologists. In general, however, they are sufficiently defined, although Mr. LEA has imposed new names of his own upon species long before described by others, evidently wishing to be considered sole authority in this branch of Conchology. Few, however, will be willing to take his ipse dixit for the justice of his claims.

Colour of the nacre. This has been supposed to be characteristic of certain species, which, it is said, never vary materially in the colour of the interior. Thus, Unio ater, LEA, U. torsus, $\mathbf{R}_{\mathrm{AF}}$. and some others are invariably purple or rose coloured; but in others again, the nacre varies from pure white to every shade of salmon, rose colour, pink and purple. The * Unio nasutus, of $\mathrm{SAY}$, is a good example of

* Mr. Lea observes that the $L$.nasutus is "either white or approaching salmon colour under the beaks." I, many 
the mutability of colour, and presents every shade of salmon colour and purple, whilst other specimens are pure white; others again bluish and highly irridescent. Amongst those hitherto found only white in the nacre, I can show examples of Unio reflexus, $R_{A F}$. (U.cornutus, BARnes, and $U$. verrucosius, $\boldsymbol{R}_{A F}$. (U.tuberculatus, BaRnEs,) which are purple. I found five specimens of the former in the Black Warrior river, near Erie, and three in the Alabama river, all purple; four of them a deep shade of that colour. They accompanied others of the same species, perfectly white. I found at Erie only one specimen of $U$. verrucosus, which is purple, and the tint is pale. The colour of most species is apt to vary in the different rivers. Thus most of the Unios of Bayou Teche are distinguished by a pearly lustre, approaching more than is usual in the American Naiades to the peculiar brilliancy of the pearl oyster.

Some of the small streams in Alabama contain shells that I have not found in the rivers to which they are tributary. Thus Unio declivis, SAY, $U$. flavus, RAF. (U. rubiginosus, LEA,) U. stramineus, nob. $U$. perovatus, nob. appear to inhabit only the

years since, found it in the Schuylkill of a purple colour, but the finest specimens of this variety were found in Chester river, Md. by Mr. Thomas Fisher. 
small streams. RAFINESQUE observes of the $U$. flavus, that it is "found only in the small rivers falling into the Kentucky, Salt or Green rivers." It occurs, however, in Alabama, where it observes the same peculiarity in the choice of its habitat. Other species prefer the soft muddy shores to the bars, which are the usual localities of the Naiades; amongst these are Unio teres, RAF. (U. anodontoides, LEA, ) and U. cariosus? SAY: U. fragilis, RAF. (U. gracilis, Barnes, Symphynota gracilis, Lea,) is abundant on the rocky shores of the Alabama river, at Claiborne, as well as on many of the bars.

The limited range of some fresh water shells, and the wide distribution of other's is very remarkable. A large Paludina adheres to the rocks in the vicinity of Claiborne in vast numbers, yet I have not elsewhere observed it, not even at St. Stephens, on the Tombeckbe, where fragments of the rocky strata strew the margin of the river in the same manner as at Claiborne, and such calcareous mas ${ }^{2}$ s appear to be the only resort of the species. In like manner the *Fusus fluvialis of SAY appears to be limited to the

* Io fusiformis, LeA. It was improper to change the specific name of this shell, for good or bad specific names it is generally conceded, must stand, unless they are preoccupied in the same genus. The animal of this shell is 
rocky bed of the Holston river. On the contrary, the Paludina ponderosa, $\mathrm{S}_{\mathrm{AY}}$, seems a common inhabitant of all the rivers of the West, from the northern districts of Indiana and Illinois to the waters of the Tennessee Valley. The same remark will apply to several species of Unio, such as $U$. niger, $R_{A F}$. ( $U$. cuneatus, BaRNes,) U.reflexus, $R_{\text {AF. (U. }}$ cornutus, BARnes, and $U$.triangularis, $R_{A F}$. Different species are found occasionally to have remarkable and strongly contrasted peculiarities in the choice of habitats; thus Anculotus pictus, nob. adheres only to pebbles on the bars, in the Alabama river, whilst Anculotus teniatus, nob. and a pretty species of ${ }^{\circ}$ Melania, are exclusively devoted to the soft calcareous banks of the same river, which they perforate like the lithophagous Testacea, giving it a honeycomb appearance, for they are extremely numerous. Fresh water shells, in general, are very partial to waters flowing over a bed of limestone or calcareous earth, and many a limpid stream have I seen, strongly impregnated with lime, whose rocky bed was paved, as it were, with myriads of univalves. The bivalves are also peculiarly abundant in those rivers of North Alabama and Tennessee, which have cut their channels in the carboniferous limestone,

doubtless the same as that of Melania, with which genus it has a close affinity. 
and where generally a long grass affords them a secure hold against the rapid current of these mountain streams. The expansion of the Tennessee river, known by the name of Muscle shoals, is of the character I have described; it is shallow, ornamented with a number of small islands, and its bed is full of the long grass which abounds in various species of Naiades. The lover of the grand and the beautiful in natural scenery, as well as the student in science, will here find abundant sources of interest. He will be delighted with a noble river, whose beauiful and numerous islands are clothed with gigantic trees; whose high and undulating shore on one hand is ornamented with thriving villages, and on the other spreads out an extensive alluvial, rich in all the gifts of Ceres, or rises abruptly from the river a mural escarpment of carboniferous limestone, which reflects its blue and sombre aspect in the crystal waters at its base. Like many other spots, however, remarkable for their loveliness, the subtle messengers of death have chosen it for their abode, infusing the poison of their breath into the serenity of autumn, when the transparency of the air and the purity of the sky, together with the gorgeous scenery, present at first to the unconscious traveller, sensations alone of health and enjoyment.

Elk river has a bed of limestone, which is also 
covered with the coarse grass, of which domestic animals as well as deer are so fond. I have observed cows and hogs feeding on it with an avidity that bespoke it a luxurious banquet. Hogs will plunge their heads entirely under water in search of this favourite food. So abundant in it are the Naiades, that the shells have been collected in one spot in sufficient abundance, when burnt into lime, to build several chimneys. Blue water creek takes its name from the limestone which imparts a blue colour to its shallow stream: I noticed few shells in this creek. Shoal creek is similar, but wider, and the rocks are covered with univalves. It is worthy of remark that the shells of the Tennessee Valley differ in their general character from those of the waters flowing into the Gulf of Mexico; thus the Tennessee and its tributaries do not contain Unio decisus, LEA, U. trapezoides, Les, U. Alabamensis, U. arctatus, nob. \&c. amongst the most abundant in South Alabama. The head waters of the Black Warrior supplied me with univalve and bivalve shells, which the most patient search did not enable me to find in the same river, as far south as Erie, and, doubtless, like other inhabitants of mountain districts, they prefer their limpid streams and rocky beds to the gravelly bars and turbid waters of the same rivers, where they flow through an alluvial country.

Whilst in the Tennessee Valley, I frequently ob- 
served great numbers of Unios, of species very familiar to me, scattered over the cultivated fields, often at the distance of a mile or more from the Tennessee river, and not nearer to any other stream. It is usually supposed by the country people that they were left in such situations by the Indians, who collected them for the luxury afforded by the animal inhabitants; but they appear to be alluvial deposites, the result of ancient inundations, as the land on which they occur has not been overflowed since that portion of our country was first cultivated by a civilized people. Similar deposites of fresh water shells are extensively distributed on river lands in Georgia, and they appear to me analogous to those vast beds of Rangia cyrenoides, on which the city of Mobile is built, and which exist on all the alluvial coast of the Gulf of Mexico, between Pensacola and Franklin in Louisiana.

In the southern rivers, great numbers of the Naiades are annually destroyed by the rapid subsidence of the waters, which leaves them exposed to an ardent sun. When they have travelled some distance and fail to reach the water, they burrow deep into the moist gravel, and soon perish if the river should not speedily rise. They are also exposed to the attacks of herons and crows, which devour great numbers of them. Hogs, I have been informed, also 
feed upon them; but some species, I should think, were thick enough to defy the masticating powers of that animal.

1 have observed, that when the waters first fall in the summer, and the bars are suddenly exposed, the Naiades can be procured in greater abundance than later in the season, when the waters have been low for a month or more. Indeed it was only in the early subsidence of the freshets, that I was able to procure some rare and highly interesting species.

The geographical distribution of the various species of fresh water shells has been little attended to. In order to attract the attention of naturalists to this subject, I will make a few observations on the facts connected with it, which have been furnished by my recent journey through Alabama. The sources of those rivers which pour their collected waters into the bay of Mobile, are divided from the tributaries of the Tennessee river by a range of mountains of no great elevation, and which are composed of carboniferous limestone. The head waters of the Black Warrior are but a few miles distant from the sources of other streams flowing into the Tennessee, yet the general character of the shells is different, a few only being common to the streams, running in opposite courses, whilst in the Black Warrior, as far 


\section{7}

south as Erie, the number of species which also occur in the Tennessee is considerably increased; amongst these are Unio rectus of LAMARCK, U. acutissimus, LeA, U. teres, RAF. U. plicatus, SAY, $U$. reflexus, RAF. U. verrucosus, RAF. and $U$. undatus, Barnes.

Unio interruptus, $\mathrm{S}_{\mathrm{AY}}$, does not inhabit the Black Warrior, and is rare in the Alabama above Claiborne; six miles below this village, it is very abundant on an extensive bar.

$U$. stapes, LEA, inhabits both these rivers, and has as yet been found in no other; it is extremely rare.

Unio arcus, nobis, I have found only in the Alabama.

Unio acutissimus, LEA, is very rare in the rivers abovementioned, but is abundant in Flint river, a tributary of the Tennessee.

Unio decisus, LEa, has been confounded with $U$. scalenius, $\mathrm{RAF}_{\mathrm{AF}}$ but is very distinct. It has, as yet, been found only in the Black Warrior and Alabama rivers; in the latter very abundantly.

Unio Alabamensis, nob. The observations on B 2 
the distribution of the preceding species apply equally well to this.

Unio asper, LEA, appears to be confined to the same waters. It has been confounded with $U$. apiculatus, $\mathrm{SAY}_{\mathrm{Y}}$, a species from Bayou Teche, but it is certainly distinct. The tubercles are not disposed in regular series as in the apiculatus.

Unio arctatus, nob. This species is usually found on the rocky shores of the Black Warrior and Alabama rivers; I have not observed it in other streams. It is usually white in the nacre, only one specimen of the many I obtained being purple. It resembles a variety of $U$. purpureus, $\mathrm{S}_{\mathrm{AY}}$, which inhabits the Delaware, but is much more elongated.

Unio glans, LEA. I never found it in the Black Warrior, yet it is not uncommon in a tributary of the Tennessee, which has its source within a few miles of the head waters of the Black Warrior. It resembles $U$.parvus, Barnes, but is purple in the nacre, which is not so brilliant as in that shell. Its outline is more regularly elliptical than that of the parvus. It approaches $U$. lienosus, nob. but is very distinct.

Unio tcriatus, nob. U. cor, nob. U. maculatus,

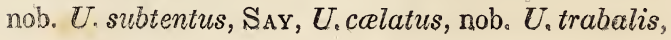


nob. U. alatus, $\mathrm{SAY}$, Anodonta declivis, nob. To all these species the remarks I have made upon the habitat of $U$. glans are equally applicable.

It will be observed that $I$ have not adopted the genus Symphynota, of LEA, not only for the reason given in the Monthly American Journal of Geology, edited by Mr. Featherstonhadgh, that as the essential character of Symphynota is the testaceous connexion of the valves, it must necessarily include some marine shells, such as Pinna, Hyalcea, \&c. but inasmuch as all other bivalves are arranged by the character of the hinge, the disposition or absence of teeth, \&c. I find no good reason for such anomalous grouping of shells, without any regard to those characters deemed essential in all other genera. In several species this connexion is so obscure as only to be observed in the most perfect specimens, and Mr. LEA has met with a specimen of the Unio ochraceus, of SAY, which will doubtless require very careful nursing to enable it to keep its station in the anomalous ranks of his genus Symphynota. Unio, Alasmodonta and Anodonta can generally be distinguished even by external form, and constitute very natural groups, closely allied, it is true, but not more so than many well established genera of marine bivalves; and yet as some species of each of these genera are connate, they are forcibly separated from their respective 
congeners by Mr. LEA, who thus builds his artificial genus Symphynota on the ruins of several well defined and natural genera. Indeed, it is yet sub judice, whether or no all the Naiades are connate in the young state. When perfect, $U$. ater, LEA, and $U$. trapezoides, LEs, are both connate behind the ligament, but cabinet specimens do not show it.

The testaceous connexion of many species is so extremely thin and fragile, that the action of the current, and the sand shifting on the bars wear it completely away. Unerring nature has formed it thicker and stronger in the weaker and more fragile species, in order to give support to a portion of the shell which otherwise would be peculiarly liable to injury. In one species of Unio, the ater of LEA, the hinge is connate only whilst the shell is young. As it advances in age, the shell becomes thick and ponderous, and loses its station in the ranks of Symphynota, doubtless, because it no longer needs the essential character of that genus. In Mr. Poulson's cabinet is a remarkable specimen of Unio plicatus, of $\mathrm{S}_{\Lambda \mathrm{Y}}$, which approaches the alated shells, and appears to have bcen connate behind the ligament; and I found in the Alabama river a specimen of Unio trapezoides, LEA, which possesses a similar character. The testaceous matter of the shells of the Naiades, always covers a portion of the ligament, and when not ex- 


\section{1}

tending entirely over it, the superior portion is always extremely thin, has the appearance of being fractured, and a part of it worn away. Future observation must determine the number of those species, which are connate when young, and occurring in situations where they are least liable to injury. If all fresh water bivalves, possessing the coalite hinge, are to constitute one genus, upon the same principle, we must arrange the analogous marine shells in a similar group, and Pinna, Mytilus and Hyalce must all have one new and descriptive generic appellation, if Mr. LEa will not admit them into his genus Symphynota, which name he may apply to the marine connate shells, as Metaptera, of Rafinesque, has priority among the Naiades.

Amongst the fresh water shells described by $\mathrm{Mr}$. $\mathrm{LEA}_{\text {, }}$ is the habitation of the larva of an insect, formed of a concretion of sand. He gives Cumberland river as the locality of this supposed shell, but it occurs abundantly in Wissahickon creek, where I found specimens more than twelve years since, and it has long been well known to the first Conchologist in the United States, the distinguished Mr. SAY, whose profound knowledge of Entomology and Conchology would not permit him to regard as a species of Valvata, a turbinate concretion of sand, formed for its habitation by the larva of an insect. There is 
another kind of these curious domicils in Wissahickon creek, so perfectly like a Crepidula, that it might with equal propriety be added to the species of that genus. Should Mr. Lea obtain this, he may erect a new genus to receive it; as fresh water and marine shells, according to his theory, cannot with propriety be arranged in the same genus. The shellformed receptacle of the Phryganea, called by this writer Valvata arenifera, is widely distributed throughout the United States. It abounds near Philadelphia and in the vicinity of Baltimore, and I have found it equally abundant in a creek in South Alabama. I never mistook it for a shell, not even when I collected it, during my solitary rambles in early youth, along the wild and romantic banks of the Wissahickon, where a passion for the beautiful in nature, as well as a taste for natural science, often led me on the fine days of autumn and spring.

It is with pleasure I acknowledge the assistance I have received in prosecuting my researches, from the kindness and liberality of several gentlemen in Alabama. I shall ever feel grateful to them for their attentions to a stranger, who sought health in the bland air of a southern clime, and recreation and instruction in the study of fossiliferous strata, in a State, probably the richest of the Union in organic remains, and certainly more interesting than any 
IT seems necessary to mention, that in the description of the bivalves, I adopt the arrangement instituted by Broderip and Sowerby, and term the distance from anterior to posterior extremity, the length of the shell; the height or elevation is from beaks to base. This nearly corresponds with the natural position of the shell, when the animal is travelling in the bed of a stream. The terms compressed, ventricose or inflated, are probably more descriptive than broad, narrow, \&c. and are therefore used in preference, according to the practice of most authors. I make no innovations, but merely adopt such a mode of description used by others as seems most natural and intelligible. 


\section{F R E H W A T R SHELLS。}

\section{UNIO POULSONI.}

\section{Plate I.}

DESCRIPTION .

SHell ovate, somewhat inflated, subalated, connate, with a blackish epidermis, profoundly wrinkled posteriorly; umbones not prominent; beaks hardly elevated above the dorsal line; ligament margin slightly arched; anterior side very short, and narrowed; posterior side somewhat produced, and truncated at the extremity; two obscure carinæ radiate from the beaks behind the umbonial slope; region of the umbonial slope inflated; anteriorly somewhat contracted and gaping at the base; cardinal teeth directed obliquely backwards; very thick and sulcated; lateral teeth short; very distant from the cardinal teeth, and granulated; within dark purple; posterior margin iridescent. 
OBSERVATIONS.

This large species is remarkable for its resemblance to two very different species, $U$. alatus, of $S_{A Y}$, and U. ater, of LEA; it has an outline not unlike the former, but is less winged and much more convex; it is less inflated and more elongated than the latter, and is more angulated and truncated on the posterior margin. The cardinal teeth are directed obliquely forwards in $U$. ater; in this species they are, on the contrary, directed obliquely backwards. It is not an uncommon species in the Black Warrior river, in North Alabama, where I procured them in six or eight feet water, in the centre of the stream; the purity of the water enabled me to detect them with facility, although a very small portion of the shell projected above the surface of the mud in which they were always imbedded. I obtained them by means of a long pointed stick, with the extremity inserted between the gaping valves, which the animal immediately closed with such force, that I could readily draw them from their tenacious beds.

\section{UNIO T 正N I A T US。}

\section{Plate IV.-Fig. 2.}

DESCRIPTION.

Shell regularly convex and elliptical, moderátely thick, epidermis finely wrinkled, olivaceous, with regular green interrupted rays; beaks slightly prominent; umbonial slope rounded; ligament slope with a slightly impressed line; base arcuated; cardinal and lateral teeth prominent; within bluish white. 
O BSERVATIONS.

This shell is related to $U$. fasciolaris, $R_{A F}$. but is shorter, more elliptical and convex, and is readily distinguished; it cannot be confounded with $U$. fasciata, RAF. as that species is broad and angular behind, compressed, and irregularly rayed.

Inhabits Flint river, Morgan county, Alabama.

\section{UNIO TRABALIS.}

Plate III.-Fig. 5.

DESCRIPTION.

Shell narrow-elliptical, subrostrated; thick before, and very thin on the posterior margin, which descends rectilinearly and very oblique; end margin obtusely rounded; umbones broad and prominent; beaks eroded; epidermis dark olive brown, rayed; within white, and highly iridescent on the posterior side.

\section{O B S E R A TIONS.}

This shell has almost the form of $U$. nasutus, except that the umbones are far more prominent, and the rostrum is nearly on a line with the base; the habit is altogether different from that shell. Perhaps it may approximate $U$. subrostratus, $\mathbb{S}_{A Y}$, a species I have not seen; but it differs from the description in being remarkably thick on the anterior portion of the shell. 


\title{
UNIO NEBULOSUS.
}

\author{
Plate III.-Fig. 7. \\ DE S C RIP TION .
}

Shell elongated, narrow-elliptical, thin, convex, olivaceous, clouded with dark brown, and with green interrupted rays; posterior side produced, rather pointed, and truncated at the end; hinge margin slightly arched; ligament slope compressed; beaks not prominent, undulated; posterior margin oblique, and rectilinear from the end of the lateral tooth to the angle of the truncated extremity; cardinal teeth very oblique and compressed; within bluish white and iridescent, or purple.

\section{OBSERVATIONS.}

This species is allied to $U$. iris, LEA, but is readily distinguished by its narrowed posterior end and angular margin. This shell is thin and fragile, very iridescent, and generally bluish; but I have one specimen with the nacre of a deep purple colour and highly polished. I found this species only in the mountainous region of Alabama, in the Black Warpior river.

\section{UN I O C O \\ Plate III.-Fig. 3. \\ DESCRIPTION:}

Shell obliquely cordate; thick, with concentric fur- 
rows; a slight and broad depression from the beaks to the base; beaks and umbones very prominent; umbonial slope subangulated, submarginal; anterior side short, subtruncated, posterior side flattened behind the umbonial slope; epidermis rugose, olivaceous, with green interrupted rays, some of them broad; cardinal and lateral teeth much elevated, granulated and sulcated; anterior and posterior muscular impressions profound; nacre white; iridescent on the base.

O B S E R A T I O N S.

A species allied to $U$. torsus, $R_{A F}$. but very distinct; it is broader and more cordate than any of the kindred species with which I am acquainted. Young specimens have an outline much resembling $U$. undatus, of BARNES; but mature individuals are slightly produced and cuneiform on the posterior end, like some varieties of $U$. triangularis, of RAF.; young shells are beautifully rayed.

Inhabits Elk and Flint rivers, Alabama.

\section{UNIO C $\mathbb{E} L A T$ T S.}

Plate III.-Fig. 4.

DE S C R I P T ION.

Shell subtriangular, very inequilateral, much compressed; with a broad furrow extending from the beaks to the base; anterior side and umbo entire, and the remaining parts furnished with small irregular

C 2 
interrupted undulations, which are profound behind the umbonial slope; surface rough, with distant slight concentric grooves; umbones much flattened, beaks prominent; epidermis dark olive, and obscurely rayed; cardinal and lateral teeth thick; anterior and posterior muscular impressions profound; nacre pearly white and iridescent.

Unio calatus, nob. Silliman's Journal, vol. xxv. p. 338, pl. i. fig. 2.

O B SER VATIONS.

This is a remarkable and very distinct species, similar in outline to $U$. lineolatus, $R_{A F}$. It differs from all its congeners in the singular manner in which its undulations are disposed. It is nearly as much compressed as $U$.lineolatus. The epidermis in some specimens is almost black. It inhabits Tennessee, Elk and Flint rivers, and is rare.

\section{UNIO MACULATUS.}

\section{Plate IV.-Fig. 4.}

DESCRIPTION.

Shell subtriangular, compressed; valves moderately thick; epidermis much wrinkled, except on the umbones, which are smooth; brown olive, with a few very broad, and narrow intervening interrupted green rays; beaks prominent; a slight and broad furrow extending obliquely from the beaks to the base; umbonial slope subangulated, behind which the shell is cuneiform; ligament margin oblique, rectilinear; 
posterior margin obliquely subtruncated; cardinal teeth nearly transverse, subcompressed; regularly striated; posterior muscular impressions distinct, slightly impressed; nacre very white, iridescent.

O B S E R V A T I O N S.

This species is allied to triangularis, of RAF. and undatus, of BARNES; but is more compressed than either; it never assumes the obliquely elongated form of the first, but is more oblique than the latter, and the substance of the shell is not so thick; the rays are broad and interrupted, and are only visible on the umbones of old specimens. Of many specimens of undatus, which I found in Alabama, not one was rayed; this species is never destitute of rays; the epidermis is profoundly wrinkled.

I obtained the species only on the banks of Elk and Flint rivers, tributaries of the Tennessee.

\section{U N I O V I B E X.}

Plate IV.-Fig. 3.

DESCRIPTION.

Shell elliptical, ventricose, rather thin; posterior margin wide, very oblique and arcuated; end margin obtusely rounded; ligament margin slightly elevated; umbonial slope rounded; epidermis yellowish olive, clouded with brown; and with green interrupted rays, extending beyond the middle, but obsolete on the anterior margin; cardinal teeth direct, prominent, 
pyramidal; nacre bluish white and iridescent posteriorly; cavity capacious; most so under the umbonial slope.

O B S E R A TION S.

A species distantly allied to $U$. iris, LEA, but differing in its greater convexity and elevation, as well as in the peculiarity of its rays, which disappear on the anterior side; an impressed line is visible in some specimens, on the posterior submargin. I found several in the Black Warrior river, south of Blount's Springs, Alabama.

\section{UNIO GREENII.}

$$
\text { Plate IV.-Fig. } 1 .
$$

DES C R IP TION .

Shell subovate, thick before, thinner behind; anterior side not very short, rounded, beaks slightly prominent; umbonial slope straight, subangulated; epidermis wrinkled, olivaceous, rayed only on the posterior side; cardinal teeth thick; lateral teeth striated and minutely granulated; within bluish white, iridescent on the posterior margin; a short obtuse elevation passing obliquely from beneath the cardinal teeth; cavity moderately capacious.

O BSERVATIONS.

A species which cannot be confounded by an accurate observer with any other heretofore described; 


\section{3}

the anterior muscular impressions are confluent, and the posterior impressions distinct.

Not uncommon in the head waters of the Black Warrior river.

I have given this species the name of my friend, $J_{\text {ACOB }}$ Green, M. D., Professor of Chemistry in Jefferson College, a gentleman well known as a contributor to the science of Conchology.

\section{UNIO PENITUS.}

Plate V.-Fig. 1.

DES C R I P TION.

Shell triangular, very thick, except on the posterior side, ventricose; umbones flattened; beaks prominent and rounded; umbonial slope angulated; posterior margin flattened; a broad convex elevation commencing near the base and projecting on the posterior extremity, with radiating prominent lines, which dentate the margin, and concentric grooves; epidermis olivaceous, wrinkled; ligament very short; cardinal teeth double in both valves, thick, prominent, sulcated and granulated; posterior muscular impression very large and deep; nacre very white; iridescent in the cavity of the umbonial elevation; cavity capacious.

O B S ER V A TION S.

This shell has much the form of $U$. triqueter of 
RAF. It is, however, more nearly allied to $U$. ridibundus, of $\mathrm{SAY}_{\mathrm{AY}}$, and $U$. interruptus, of RAF.; the umbones are not so broad as in the latter species, and the posterior margin descends much more obliquely; none of the specimens which I found are rayed; but some are nearly destitute of the remarkable ridge which resembles that of $U$. interruptus. No species has the lateral teeth more beautifully granulated and striated. The anterior muscular impression is very deep, and remarkable for penetrating under the cardinal tooth.

Inhabits the Alabama river, near Claiborne, and is mare.

\section{UNIO MASONI.}

\section{Plate V.-Fig. 2. \\ DESCR I P T I N}

Shell suborbicular; disks slightly flattened; umbones broad, prominent, carinate behind; beaks slightly prominent; umbonial slope straight and angulated; ligament slope flattened, broad; epidermis olive, clouded with brown, polished; cardinal teeth prominent, compressed, very oblique; within bluish white; cavity of the umbo capacious.

\section{OBSERVATIONS.}

A small species, which is very distinct from any hitherto described. I found it in the Savannah river, at Augusta, in company with great numbers of $U$. congarceus, LEa, with which, perhaps, it has more 


\section{5}

affinity than with any other species. It appears to be destitute of rays.

This is the only Unio of a suborbicular form yet discovered in the Atlantic rivers. I have only two specimens, the largest of which is figured.

I have given this shell the name of my kind friend, Mr. William Mason, one of the earliest American Conchologists, whose discoveries have enriched our cabinets with many new and rare species of land and fresh water shells.

\section{UNIO DELUMBIS.}

\section{Plate V.-Fig. 3.}

\section{DESCRIPTION.}

Shell ovate, elongated, very thin and fragile, ventricose; ligament margin slightly elevated; anterior side rather narrow, posterior margin rounded; epidermis olivaceous, with green rays; umbonial slope rounded; margin of the ligament slope rounded, very oblique; within bluish, highly iridescent; cardinal teeth laminar; cavity capacious.

OBSERVATIONS.

I found this shell abundantly near Cooper river, South Carolina, in the small streams; it is more nearly allied to $U$. ochraceus, of $\mathrm{SAY}_{\mathrm{AY}}$, than to any other species; but it may be distinguished by its elon- 
gated ovate form. In the same waters a remarkable variety of ochraceus is not uncommon.

\section{UNIOAR C T A T US.}

\section{Plate V.-Fig. 4.}

DESCR I P T ON.

Shell elongated, compressed; slightly contracted from beaks to base; basal margin slightly contracted; anterior side short, narrowed somewhat and rounded on the margin; posterior side elongated, truncated at the end; subemarginate above; ligament margin elongated, parallel with the base; epidermis blackish; cardinal tooth in the left valve widely bifid, not very prominent; within bluish white.

Unio arctatus, nob. Silliman's Journal, vol. xxv. p. 340 , pl. i. fig. 9 .

O B E R V A TION

This shell has a resemblance in outline to Alasmodonta margaritifera. It approaches a variety of $U$. purpureus of the Delaware river, but is more elongated, and very distinct. Of many specimens which I found, one only was purple in the nacre. It is partial to the rocky shores of the Alabama, but is scarcely ever seen on the bars. It inhabits also the Black Warrior river. This shell resembles so much the variety of purpureus, mentioned above, and which is probably $U$. coarctata of LAMARCK, that I am inclined to believe several species of the Schuylkill, Delaware and other streams have been con- 


\section{7}

founded under the general name of purpureus. Mr. Mason, who has more thoroughly investigated these shells than any other Conchologist, has brought together in his cabinet specimens so dissimilar in appearance as to perplex the student if he admits them as varieties only of one species; for in that case he must extend his scepticism to a number of other shells, hitherto admitted as distinct species. Different localities, no doubt, produce some corresponding difference in the general appearance of certain shells, a remarkable instance of which is exhibited in $U$. niger, RAF., which in Flint river is quite a dwarfish shell, compared with the same species in other rivers. This remark will apply equally to $U$. costatus, $\mathrm{RAF}_{\mathrm{AF}}$ of Flint river; but the specific character is not lost in the varieties of these two shells, which cannot be said of the so called varieties of $U$. purpureus. Perhaps U. coarctatus, LaMr. will prove a distinct species, but I leave it for a more accurate observer to make further comments on this difficult subject. No one could do it more justice than Mr. Mason.

\section{UNIO PECTOROSUS.}

\section{Plate VI.-Fig. 1.}

DESCRIP T I O N 。

Shell oval, ventricose, not thick; posterior margin broad, biangulated; umbonial slope subangulated; space behind fiattened, with an impressed line passing from the beak to near the middle of the posterior margin; anterior side slightly produced; umbones: 
wide and prominent; beaks slightly elevated; epider mis brown olive, with angular spots disposed in form of rays; cardinal teeth direct; subpyramidal, prominent; within white; cavity capacious.

\section{O B S E R V A T I O N .}

This shell is distantly related to $U$. ovatus, $\mathrm{S}_{\mathrm{AY}}$, but is more elongated, less ventricose, and has interrupted rays; the epidermis posteriorly has numerous short vermicular raised lines. I found the species only on the bank of Elk river, near its junction with the Tennessee at the Muscle shoals.

\section{UNIO R UBELLUS。}

\section{Plate VI.-Fig. 2.}

DE S C R I T I O N

Shell suborbicular, ventricose, thick; beaks subcentral; umbones prominent; umbonial slope rounded, margined before by a faint angle; a similar angle behind the umbonial slope; beaks eroded, slightly prominent; epidermis reddish brown; cardinal teeth direct; muscular impressions small and distinct; nacre pink or purplish.

O B SER VATION S

A small species, which I obtained only in the Black Warrior, near its source, among the mountains of Alabama; it is rather an obscure species, but I can- 
not consider it a variety of any hitherto described. The figure represents one of the largest specimens which I found.

\section{UNIO F UR V US.}

Plate VI.-Fig. 3.

DE S C R IPTI ON.

Shell oval, ventricose, thick before, thinner behind, posterior margin wide, hardly angulated; umbonial slope angulated, behind which is an obscure impressed line; epidermis almost black, with minute crowded wrinkles; cardinal teeth slightly oblique, pyramidal; within white, highly iridescent on the posterior margin.

O B S ERVATI ONS.

A species which I found in the Black Warrior river, in company with the preceding; it is very rare.

\section{UNIO RA VENELI。}

Plate VI.-Fig. 4.

DESCRIPTION

Shell oblong oval; ventricose; beaks hardly prominent; ligament margin straight, not oblique; base very slightly arcuated; umbonial slope angulated, 
behind which is another obscure angle, passing from the beaks to the extremity, which is subtruncated; cardinal teeth erect, oblique, compressed; within yellowish or pale purple.

O B S R R A TIONS.

This shell resembles $U$. purpureus in outline, but it is much more convex, and the peculiar biangular posterior side will distinguish it from that species. Some specimens are rayed, and old individuals become very ventricose. One of these has a yellow epidermis, but the usual colour is olivaceous.

Inhabits the Wateree canal, South Carolina, where it was first discovered by Dr. Blanding. I have since found it in the small creeks, near Cooper river, S. C.

I have dedicated it to my friend, Professor Edmund RAVENEL of Charleston, through whose polite attention I was enabled to make a valuable collection of fresh water shells and organic remains in an interesting portion of South Carolina.

In my excursions in the vicinity of the Santee canal, I found a few shells of this species, and the following also occurred in the same waters: $U$.nasutus, Santee canal; $U$. angustatus, LEA, U. ochraceus, ? SAY, $U$. congarceus, LEA, U.delumbis, nob. and a shell which is probably a variety of $U$. purpureus, $\mathrm{S}_{\mathrm{AY}}$. 


\title{
UNIO I C T ER IN US.
}

\author{
Plate VI.--Fig. 5. \\ DESCRIPTION.
}

Shell elliptical, moderately thick; anterior margin regularly rounded; posterior margin descending obliquely, and subtruncated at the extremity; beaks not prominent; umbonial slope very oblique, nearly rectilinear, angulated; epidermis smooth and polished, olive yellow, clouded with brown on the margins; base slightly arcuated; nacre salmon coloured, iridescent on the posterior margin.

O B SERVATIONS.

A species approaching that variety of U.purpureus, of SAY, termed carinatus, by LAMARCK; but I believe it to be quite distinct. It certainly does not resemble the purpureus of the same locality.

Whilst at Augusta in the month of February, when the Savannah river had risen considerably above low water mark, I found on the muddy shore opposite the town, numbers of Unios, which had been recently taken by the muskrats. Amongst these were the two species mentioned above, $U$. angustatus, of LEA, abundance of $U$. congarceus, LEA, a remarkable variety of $U$. nasutus, $\mathrm{S}_{\mathrm{AY}}$, thick, and salmon coloured within; and a suborbicular species, very distinct from any other species I have seen. All the specimens of icterinus are more or less salmon co-

D 2 
loured in the nacre, and are smooth and polished on the exterior. The figure represents a specimen nearly of the largest size which I obtained.

\title{
UNIO TENEBROSUS.
}

\author{
Plate VII.--Fig. 1. \\ DESC RIP TION.
}

Shell elliptical, ventricose; valves rather thick anteriorly; beaks prominent; posterior margin descending oblique and rectilinear from the ligament; extremity subtruncated; epidermis olivaceous; rayed; margins dark brown; cardinal teeth moderately thick, oblique; within bluish or pink; iridescent; cavity capacious.

OBSERVATIONS.

Two specimens of this species were sent to $\mathrm{Mr}$. Poulson by Mr. Featherstonhaugh, who found them in the Rappahannock, near Falmouth, Stafford county, Virginia; I also found a single specimen in South Carolina. On comparing these with the $U$. radiatus, BARNES, I find they differ from that species in their greater convexity, and in the somewhat pointed posterior side; they are also more obscurely rayed. Those of the Rappahannock were associated with $U$. ochraceus and cariosus, $\mathrm{S}_{\Lambda \mathrm{Y}}$, precisely like those inhabiting the Schuylkill river, near Philadelphia. 
U N I O A T I L IS.

Plate II.-Fig. 1.

DESCRIPTION.

Shell suboval, thin, inflated; beaks slightly prominent and much decorticated; posterior margin subangulated; umbonial slope rounded, behind which is an obscure rib declining from the beaks to the posterior extremity; base arcuated; epidermis blackish, rugose, olivaceous over the umbones and rayed; and with numerous short vermicular lines on the posterior slope; cardinal teeth subpyramidal, erect; lateral teeth distant; a profound elongated muscular impression on the callus; nacre whitish and iridescent.

O B S E R A T I O N S.

Inhabits the Alabama river, near Claiborne, and is rather rare. Young specimens resemble in outline the $U$. multiradiatus, LEA. Old shells have the epidermis almost black.

\section{UNIO PEROVALIS.}

Plate II.-Fig. 2.

DESCR IP TION.

Shell oval, moderately thick, inflated; beaks promi- 
nent, not nearly terminal; posterior margin obliquely truncated; umbonial slope rounded; base arcuated; epidermis olivaceous, obscurely rayed, wrinkled on the margins; cardinal and lateral teeth very prominent, granulated; nacre whitish and iridescent on the posterior margin.

Variety A. Epidermis reddish brown; nacre rose coloured.

\section{OBSERVATIONS.}

I found a very few specimens of this shell at Claiborne, on the Alabama river; it is allied to $U$. multiradiatus, LEA, but on comparing it with specimens of that species in Mr. Poulson's cabinet, I found it sufficiently distinct; the nacre is denser, and thickened on the margin; and the rays are of nearly uniform size, distant and obscure. The lateral teeth closely resemble those of $U$. multiradiatus.

\section{U NIO PRASIN US.}

Plate III.-Fig. 1.

DE S C R I P T I O N.

Shell suborbicular, compressed, with distant concentric impressed lines; anterior margin obtusely rounded; posterior margin wide, truncated, not oblique; basal margin straight, parallel with the ligament margin; beaks prominent; epidermis olive yel- 
low, varied with green; two green rays behind the umbonial slope.

OBSERVATION S.

The only specimen of this shell which I have seen, is in the cabinet of the Academy of Natural Sciences, where it was placed by Mr. Schoolcraft, who found it in Fox river of Green Bay. It cannot be confounded with any known species of Unio. On the posterior side some small tubercles are disposed in a line, and one or two others are observable on the umbonial slope.

\section{UNIO INFUCATUS.}

\section{Plate III.-Fig. 2.}

DESCRIPTION.

Shell short oval, compressed, posterior margin wide, slightly oblique, obtusely rounded or subangulated at the extremity; umbones wide, not prominent, beaks greatly eroded; umbonial slope subangulated, hardly curved; epidermis black; within pearly white; cardinal teeth direct, pyramidal.

OBSERVATIONS.

This shell presents nothing remarkable in its appearance, but its oval figure and compressed sides will distinguish it from the allied species; U. laviga. 
tus, $\mathrm{R}_{\mathrm{A} F}$. has most resemblance to it in habit. With age the posterior extremity becomes slightly produced.

Inhabits Flint river in Georgia.

\section{UNIO O VIFORMIS.}

Plate III.-Fig. 6.

DESCRIPTION.

Shell ovate, convex, thick anteriorly, thinner posteriorly; anterior margin rather obliquely rounded; posterior margin obliquely truncated; extremity angulated; beaks prominent, not decorticated, with three or four strong interrupted undulations; lunule ovate; umbonial slope rounded; epidermis light yellowish olive, with broad crowded green rays, widely interrupted; cardinal teeth direct; within pearly white, highly iridescent posteriorly.

\section{O B S E R V A TION S.}

A beautiful species, allied to $U$. scalenius, $R_{A F}$. It differs in not being sinuous or compressed; and in having undulated beaks. It is not oblique.

It inhabits rivers in Tennessee, but I know not the exact locality. It was presented to me some years since by Mr. Brewster, of Mount Pleasant, Tennessee, to whom I am indebted for the finest specimens of certain species which have reached our cabinets. 


\title{
UNIO PEROVATUS.
}

\author{
Plate II.-Fig. 3.
}

DE S C R I P TION.

Shell ovate, rather ventricose, valves thick on the anterior side, thinner posteriorly; anterior margin regularly rounded; basal margin rounded; posterior extremity subangulated; beaks rather elevated, approximate, undulated; epidermis olive, wrinkled on the margin; cardinal teeth erect and prominent, not very thick; nacre white.

Unio perovatus, nob. Silliman's Journal, vol. xxv. p. 338 , pl. i. fig. 3 .

\section{O B S E R V A T I O N S.}

The regular ovate form of the shell will distinguish it from most other species; the young shell, however, is broader behind, approaching to an oval figure, and is ornamented with green rays on an olive yellow ground. It inhabits small streams in Greene county, Alabama.

\section{A NODONTA TERES.}

Plate VII.-Fig. 2.

DESCRIP TION.

Shell narrow-elliptical, inflated; posterior side pro. 
duced; margin oblique and rectilinear; truncated at the extremity; basal margin hardly arcuated.

OBSERVATIONS.

This shell attains a length of four or more inches, and is distinguished by its subcylindrical form. I found it in the Santee canal, South Carolina.

\section{PALUDINA GENICULA.}

Plate VIII.-Fig. 3.

DES CRIPTION.

Shell suboval; spire slightly elevated; volutions 4 , scalariform; shoulders angulated; apex eroded; aperture rather more than half the length of the shell; epidermis green olive; within bluish.

O B SER V A T I O N S.

A species which is readily distinguished from those nearest allied to it by the angulated whorls. I found a single specimen in Flint river, Georgia.

PALUDINA MAGNIFICA.

Plate VIII.-Fig. 4.

DES C RIPTION.

Shell obovate, ventricose, with two spiral bands of 
prominent tubercles on the body whorl, and one revolving near the base of each whorl of the spire; suture profoundly impressed, margined by an obtuse subnodulous prominent line; lines of growth very oblique and prominent; obscure spiral striæ; epidermis olive; within bluish, often with purple bands.

\section{OBSERVATIONS.}

A beautiful species when perfect, occurring in vast abundance on the masses of calcareous rock, which have fallen from the strata above, into the Alabama river, at Claiborne. I found it living only in such situations, and exclusively within a range of six or eight miles. In the Tombeckbe or Black Warrior rivers, I never observed a specimen of it, although I searched particularly for it on the rocks at St. Stephens.

\section{MELANIA EXCURATA.}

\section{Plate IV.-Fig. 6.}

DESCRIPTION.

Shell subulate, with a spiral band of slightly oblique subcompressed tubercles on the base of the inferior whorls; above this is a prominent line with a slight intervening channel; volutions towards the apex nearly entire; base with three prominent lines, the superior one largest; the third hardly prominent and approximate to the middle one. 
O B S E R V A T I O N .

A large and beautiful species, common in the Tènnessee river at Florence. It is perhaps most nearly allied to M. Sayi, (M. canaliculata, SAY,) but the elevated line and form of the tubercles will distinguish it from that species. The epidermis is reddish brown or black.

\section{MELANIA HYDEII.}

Plate VIII.-Fig. 1.

DES C R I P T O N.

Shell conical, rather elevated; whorls flattened, with spiral acute tuberculated lines, one or two only on each whorl of the spire, and about four on the body whorl, the inferior one plain; aperture elliptical.

OBSER VA T I N S

Inhabits rocks in the Black Warrior river, south of Blount's Springs, Alabama, and is very abundant. It is remarkable for its distant tuberculated lines. Young specimens are olive, with a purple band on each whorl, and are without tubercles; the body whorl is angulated, and carinated.

It is named in honour of Mr. William Hyne, an industrious and excellent Conchologist. 
MELANIA ANNULIFERA.

\author{
Plate VIII.-Fig. 2. \\ DESCRIPTION.
}

Shell elevated-subconical, with flattened whorls and elevated distant ribs, alternately smaller; about five on the body whorl and three on the adjoining one; suture obsolete; colour generally blackish exteriorly and dark purple within.

OBSERVATION S.

Inhabits with the preceding speeies, from which it differs in being less ventricose, and having the ribs plain; the aperture is shorter than in the preceding.

\title{
MELA I A S A L B R O A .
}

\section{Plate IV.-Fig. 5.}

DESCRIPTION。

Shell short, suboval, thick, ventricose, with a series of very elevated nodes on the shoulder of the body whorl, and generally two series of smaller nodes beneath; spire very short; apex much eroded; aperture about half the length of the shell, contracted; within purplish; columella with a callus above, and another near the base. 


\section{2}

OBSERVATION S.

This singular shell approaches the genus Anculotus, in form, but the aperture is that of a Melania. I found it adhering to logs in the Tennessee river, at Florence, where it is abundant. My friend, William Hodsson, JR. found it also in the Holston river, in Tennessee.

\section{MELANIA PYRENELLA.}

\section{Plate VIII.-Fig. 5.}

DE S R I P T I N .

Shell elevated, with flattened whorls, having an obsolete spiral line on each; suture impressed; body whorl angulated; angle defined by a prominent line; base hardly convex; labrum angulated near the centre; aperture patulous; columella obtusely rounded at the base.

O BSERVATIONS.

Inhabits streams in North Alabama. The aperture is remarkably patulous and the labrum profoundly angulated.

MELANIA BIT $\mathbb{E}$ I A TA.

Plate VIII.-Fig. 6.

DES CRIP TION.

Shell conic, with convex whorls; spire short; one 


\section{3}

whorl entire, very convex; apex eroded; colour olive, with two broad purple bands on the body whorl; one on the contiguous whorl; columella with a callus above and another near the base; aperture half the length of the shell; labrum regularly arcuated; within bluish, with purple bands.

OBSERVATIONS.

Inhabits the Black Warrior river. It is a rare species, remarkable for its broad purple bands and convex whorls.

MELANIA C OM M .

Plate VIII.-Fig. \%

DESCRIPTION.

Shell subulate, much elongated, slender; whorls eight or nine, flattened, indented at the sutures, with longitudinal distant, slightly arcuated ribs, disappearing on the lower volutions; labrum thin; aperture elliptical, produced at base; colour olive, with a dark band above the middle of each whorl.

O B S E R V A TIONS.

Inhabits rivulets which are tributary to the Black Warrior in mountain districts, in Alabama. It is greatly elongated, and the ribs are separated by an indented space at the suture.

E 2 
Plate VIII.-Fig. 8.

DES CRIP TION .

Shell conic, or subfusiform; with approximate nodulous spiral lines of unequal size; body whorl angulated; angle with a series of prominent tubercles; base with two lines, the superior one nodulous; aperture nearly half the length of the shell, contracted, and acutely angular above, and obtusely pointed at base; labrum very thin; colour olive; within with purple bands.

\section{O B S E R A T I ON S.}

A fine species, easily recognised by its numerous tubercles, and ventricose form. Inhabits Elk river, Alabama, adhering to stones, and is a common species.

MELANIA ALVEARE.

Plate IV.-Fig. 7.

DES C R IP T I ON.

Shell short conical, ventricose; whorls flattened, with a line of wide compressed tubercles at the base of the penultimate whorl; body whorl angulated; angle armed with prominent tubercles; base hardly convex, with about five prominent lines; aperture 


\section{5}

obliquely elliptical; less than half the length of the shell.

O B S E R V T I O N S

Inhabits with the preceding species. The spire is very regularly conical, and the base strongly ribbed.

\section{MELANIA NASSULA.}

$$
\text { Plate VIII.-Fig. } 9 .
$$

D ES C RIPTION.

Shell elevated, whorls convex or subangulated, with longitudinal ribs, crossed by numerous spiral elevated lines, about seven on the penultimate whorl, and about eleven on the body whorl; suture impressed; apex much eroded.

OBSERVATIONS.

Inhabits the limestone spring at Tuscumbia, Alabama. Immense numbers of this pretty species congregate on the rocks where Spring Creek finds a passage through a cavern of the carboniferous limestone.

MELANIA CYLINDRACEA.

Plate Vili.-Fig. 10.

DESCRIPTION.

Shell subcylindrical, smooth, with a short spire, 
the whorls of which are small; apex eroded; body whorl elongated, obtusely rounded above, and at base; aperture more than half the length of the shell, narrow, much contracted above.

\section{O B S E R V A T I O N S.}

This species is remarkable for the rude, almost deformed whorls of the spire. It inhabits the Tombeckbe river, on the soft limestone banks, and is generally coated with a calcareous deposite.

\section{MELANIA TROCHIFORMIS.}

\section{Plate VIII,-Fig. 11. \\ DE S C R I P T I O N .}

Shell short conical, ventricose, turreted; two spiral prominent lines on each whorl, the intervening spaces concave; summit of the whorls flattened, angulated; body whorl angular, with the periphery carinated; base flattened; aperture small; labrum angulated in the middle.

O B S E R A T I O N .

A species easily recognised by its strong ribs, or by its sulci, and its trochiform shape. Inhabits streams in North Alabama. 
MELANIA VESTITA.

Plate VIII.-Fig. 12.

DES C R I P T I ON .

Shell subulate, subturreted; volutions nine; each angulated below the middle; suture deeply impressed; epidermis smooth, polished, horn coloured, with a dark band revolving below the angle of each whorl; whorls near the apex acutely carinated.

O B S ERVA TIONS.

Inhabits small streams in Greene county, Alabama, among the grass which grows on the rocks. The shell is always coated with a deposite, which obscures its characters.

\section{A NCYLUS FILOSUS.}

D E S C R I P TI ON.

Shell regularly oval, rather elevated; with numerous radiating prominent lines; apex very prominent, inclined, eroded, not nearly central.

O B S E R V A T I O N .

Inhabits the Black Warrior river, south of Blount's Springs, Alabama. It is abundant on various species of Melania. 


\title{
M ONOGRAPH
}

\author{
OF THE
}

\section{GENUS ANCULOTUS OF SAY.}

\section{A N C ULOT US.}

GENERIC CHARACTER.

Shell suboval, rarely conical; spire generally depressed; aperture suborbicular or obovate, rounded at base; base of the columella rounded or obtusely angulated; columella wide, thickened, polished, generally with a callus near its superior junction with the labrum.

\section{OBSER V A T I O N S.}

Mr. SAY, with his usual discrimination, has separated this natural group of shells from the genus Melania, from which they differ in their obtusely rounded base, and generally by their depressed form, several spe- 
cies having almost the shape of Natica. They cannot be confounded with Paludina, because the labium is thickened, the duplication uniting above with the labrum, and the aperture is also acutely angular above. I believe all the species adhere only to calcareous banks or to stones; never travelling in the sand like many species of Melania and Paludina.

\section{A NCULOTUS PREROSUS.}

$$
\text { Plate VIII.-Fig. } 13 .
$$

DESCRIPTION。

Shell suboval, ventricose; spire very short, much eroded at the apex; body whorl contracted near the middle by a broad slight channel; epidermis horncoloured, with dark angular spots disposed in bands; distinct on the interior of the labrum; base deeply indented behind the columella; columella angulated at base; aperture subovate; acute above. Length three-fourths of an inch.

Anculotus prcerosus, SAX. Journal of the Academy of Natural Sciences, vol. ii. p. $17 \%$.

OB S E R A T I O N S

Inhabits the Ohio and Tennessee rivers.

I have a variety less ventricose, and without any indentation at base. 


\title{
60
}

\section{A N C ULOT US 'S UBGLOBOSUS.}

\author{
Plate VIII.-Fig. 14.
}

DESCRIPTION.

Shell subglobose, with a depressed convex spire; epidermis olivaceous with variable greenish spiral bands; interior bluish, with purple spots or bands; labrum thin; aperture rounded, nearly as long as broad; labium a little flattened.

Anculotus subglobosus, SAY. Journal of the Academy of Natural Sciences, vol. v. p. 128.

O B SERVATIONS.

Inhabits the Holston and Tennessee rivers, adhering to rocks and stones. Young shells have the apex acute, and perfect.

\section{ANCULOTUSA NGULATUS.}

\section{Plate VIII.-Fig. 15.}

DESCRIPTION 。

Shell subglobose; body whorl ventricose, contracted above; biangulated; spire very short; volutions carinated at the suture; colour olivaceous, with about four series of dark quadrangular spots on the body whorl. 


\section{1}

O B S E R V A TI O N S

Inhabits Flint river, Morgan county, Alabama, adhering to stones, and is common.

\section{A NCULOTUS PLICATUS.}

Plate VIII.—Fig. 18.

DESCRIPTION.

Shell suboval, with a short spire, only one whorl of which is entire, rounded; body whorl slightly ventricose, with oblique plaits or lines, which are crenulated on the margins of a slight spiral groove near the suture; lines of growth prominent; epidermis greenish or blackish, with spiral bands; aperture elliptical.

O B S E R V A T I O N S.

Inhabits tributaries of the Tennessee river in Alabama, adhering to stones.

A NCULOTUS MONODONTOIDES.

Plate VIII-Fig. 16.

DESCRIPTION .

Shell subglobose, body whorl ventricose, not abruptly rounded above; apex eroded; columella with a 
large pyramidal tooth at the base; epidermis horn coloured, with obscure bands; aperture effuse.

O B S E R A TI ON S.

Inhabits streams in Virginia. Mr. Hyde.

I received a specimen of this curious species from Professor Green of Jefferson College.

\section{A N CULOTUS PICTUS.}

DESCRIPTION.

Shell oval; spire short, convex; apex eroded; body whorl slightly compressed in the middle; epidermis horn-coloured, with numerous series of small angular spots; spots distinct within on the labrum; aperture obovate, base regularly rounded. Length fiveeighths of an inch.

Anculosa picta, nob. Silliman's Journal, vol. ii. p. 342. pl. i. 15.

O B SERVATION .

Inhabits pebbles on the bars in the Alabama river, near Claiborne.

\section{A NCULOTUS PUMILUS.}

DESCRIPTION .

Shell very small, obliquely oval, blackish; spire consisting of one entire convex whorl; apex eroded; 
body whorl regularly convex; base with a groove behind the columella; aperture suborbicular, patulous.

O B S E R A T ION S.

Inhabits the Black Warrior river and Bayou Teche; the latter locality was communicated by Professor Green, who supplied me with a specimen.

\section{ANCULOTUS T $巴$ INIATUS。}

DESCRIPTION。

Shell oval, or oblong; olivaceous, with dark green spiralbands, four on the body whorl; one whorl of the spire not eroded, often longitudinally produced. Length three-fourths of an inch.

O B S ER VATION S

* Inhabits the friable calcareous banks of the Alabama river, at Claiborne. It is a pretty species, remarkable for its dark bands, which resemble those of Melania olivula, nob. of the same locality.

* In my observations on the habits of this shell, I inadvertently stated that it was exclusively devoted to calcareous banks. I found them also on a siliceous breccia, near Claiborne. 


\title{
ANCULOTUS MELANO1DES.
}

\author{
Plate Vill.-Fig. 19.
}

DESCRIPTION.

Shell conical, with three entire volutions; apex eroded; whorls flattened, rounded only at the sutures; lines of growth prominent; body whorl abruptly rounded; epidermis blackish, obscurely banded; aperture elliptical, about half the length of the shell. Length half an inch.

OBSERVATIONS.

Inhabits rivers in North Alabama.

\section{A N CULOTUS NIGRESCENS.}

\section{Phate VIII.--Fig. 1\%.}

DESCRIPTION.

Shell subconical, truncated or much eroded at the apex; superior whorl hardly convex; body whorl elongated, contracted above on the labrum; columella flattened, obtusely rounded at the base; aperture obovate, rather more than half the length of the shell; epidermis blackish; within dark purple.

I am indebted to Mr. Hrde for this shell; he informs me it inhabits rivers in Maryland. 
I am indebted to the politeness of Mr. Poulson, for an opportunity to consult his library and collection, in order to prepare the following Table of the species of Naiades, inhabiting the North American rivers. Most of those which have been described by Rafinesque, have been added by that author to Mr. Poulson's valuable collections, with the names attached to each; but I have considered some of these as merely appertaining to varieties, and have given them among the synonymes of the different species, to which I think they properly belong. Mr. PouLson deserves the thanks of Conchologists for the pains he has taken to rectify the confused nomenclature of American Naiades, a task which has been attended with considerable labour and expense. 



\title{
SYNOPTICAL TABLE
}

OF THE

\section{SPECIES OF AMERICAN NAIADES,}

\author{
WITH
}

SYNONYMES.

\section{U N I O}

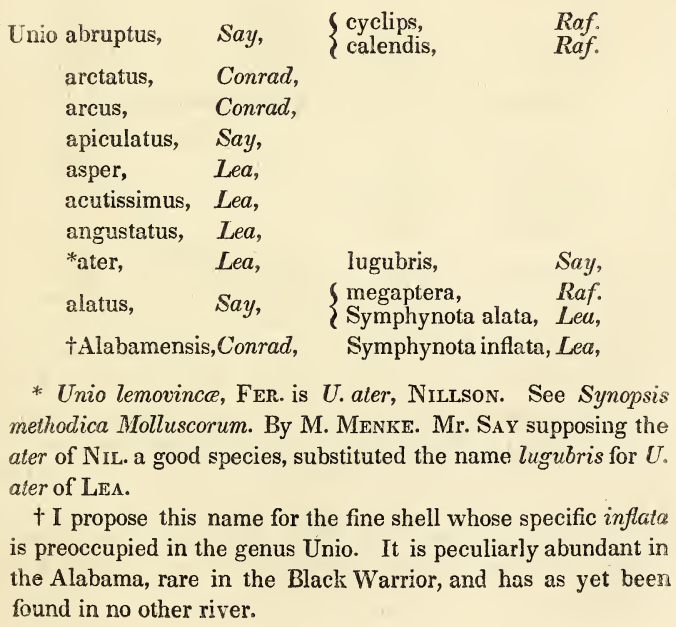




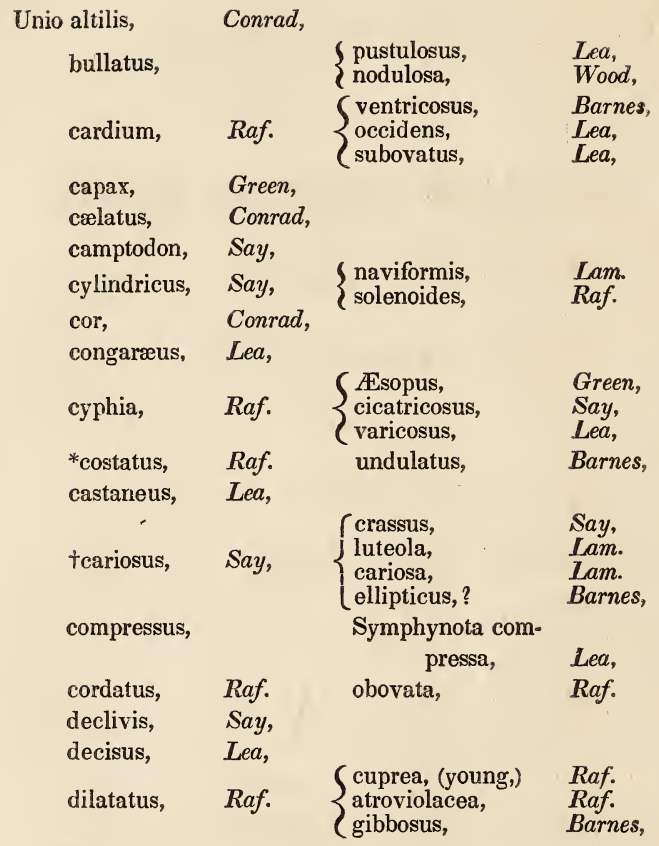

* There is so great a difference in the colour of the epidermis in a variety of this shell, that it may be considered distinct by some Conchologists. The specimen described by RAFINESQUE had a yellow epidermis, that of BARNES was black. I found both varieties in the streams of the Tennesee Valley, in Alahama.

† Mr. LEa gives carinatus, of BARNES, among the synonymes of this species, but it is very distinct. It is the fasciata, of RAFINESQUE. 


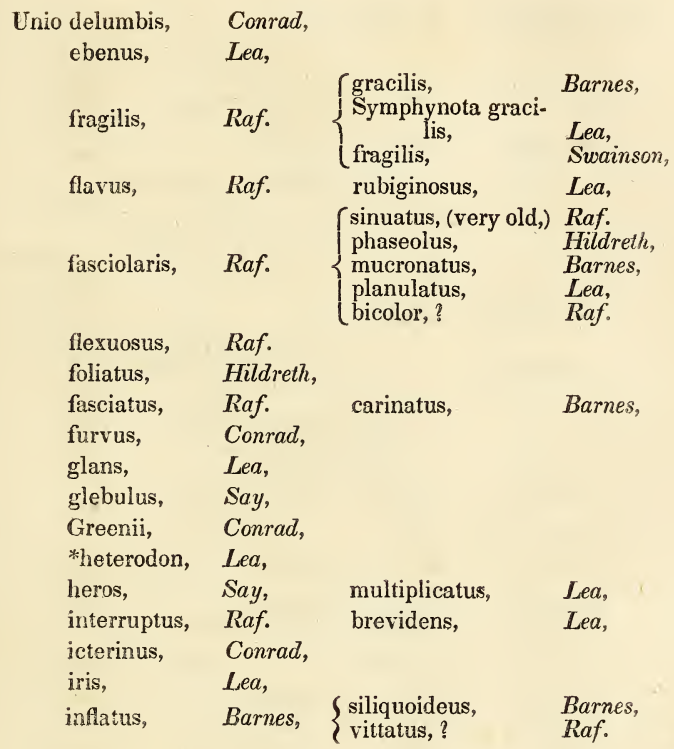

*'This species was first named heterodon by my father, in conversation with $\mathrm{Mr}$. MASON, long before the description was published or even written. Mr. Mason communicated the name as well as the species to Mr. LEA, who gives his friend credit neither for the name nor for discovery of the fact that the lateral tooth is double in the right valve, as in justice he should have done. I make these remarks, because Mr. LEA insists that U. plicalus, SAY, must be credited to Leseuer; and, if so, the species in question must be called $U$. heterodon, of MAson, as the circumstances under which these two species were described are parallel. 
Unio infucatus, Conrad,

lienosus, Conrad,

$\begin{array}{lccc}\text { lineolatus, } & \text { Raf. } & \begin{array}{l}\text { depressa, } \\ \text { ellipsaria, } \\ \text { securis, } \\ \text { fabalis, }\end{array} & \begin{array}{l}\text { Raf. } \\ \text { Raf. }\end{array} \\ \text { lapillus, } & \text { Say, } & \text { Lea, }\end{array}$

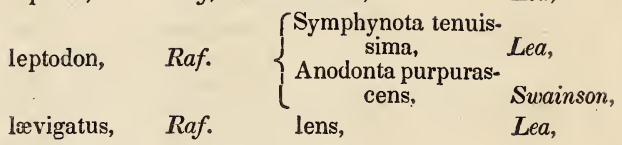

lanceolatus, Lea,

lævissimus,

SAnodonta ohiensis, Raf. $\left\{\begin{array}{c}\text { Symphynota lævis- } \\ \text { sima, Lea, }\end{array}\right.$

latus,

monodonta, Say,

SAnodonta lata, Raf.

\{dehiscens, Say,

multiradiatus, Lea,

metanever, Raf.

metallicus, Say,

soleniformis, Lea,

Masoni, Conrad,

maculatus, Conrad,

nervosa, Raf

nasutus, Say,

niger, $\quad$ Raf

nodosus,

Barnes,

cuprinus,

Lea,

nodulatus,

Raf.

zig-zag, ?

Lea,

rostratus,

Val.

cuneatus,

Barnes,

nexus,

nebulosus,

Say,

$\{$ pustulatus,

Lea,

Val.

arcæformis,

Lea,

ovatus,

Conrad,

obesus,

Say,

ovata,

Raf.

olivarius, $\quad \boldsymbol{R} a f$.

ochraceus, Say,

ellipsis,

Lea,

obliquatus, Raf.

sulcatus,

Lea

oviformis, Conrad,

penitus, Conrad,

parvus, Barnes, 


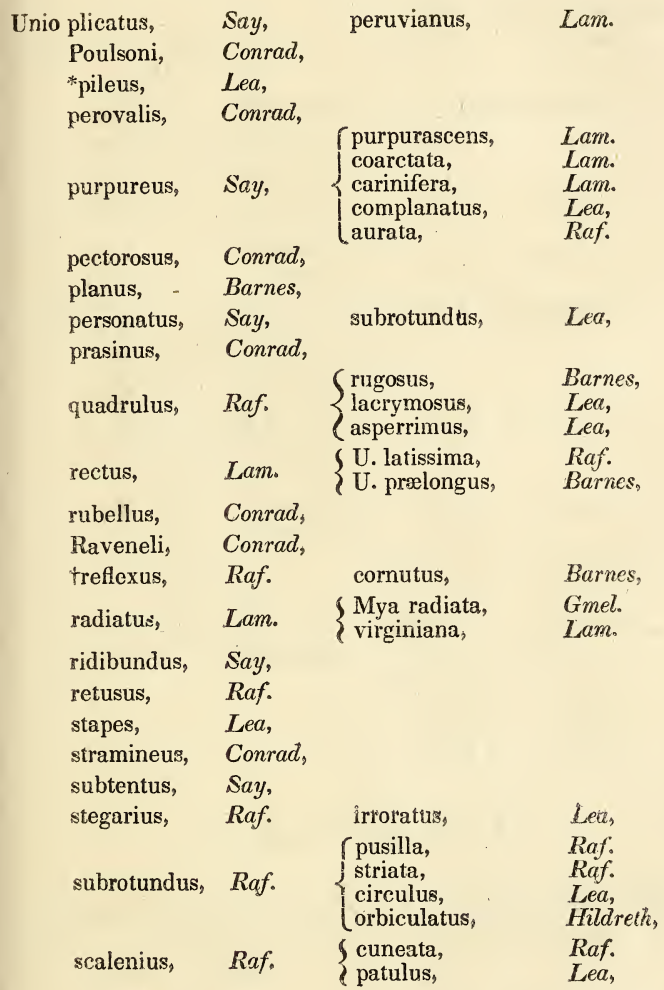

* This species nearly approaches the sulcatus, of LEA, if it be not a variety of that shell. LEA observes, "it differs from" the latter "in being more elongated and in being destitute of a purple nacre." A specimen I found in Elk river, Alabama, has a deep purple nacre. 


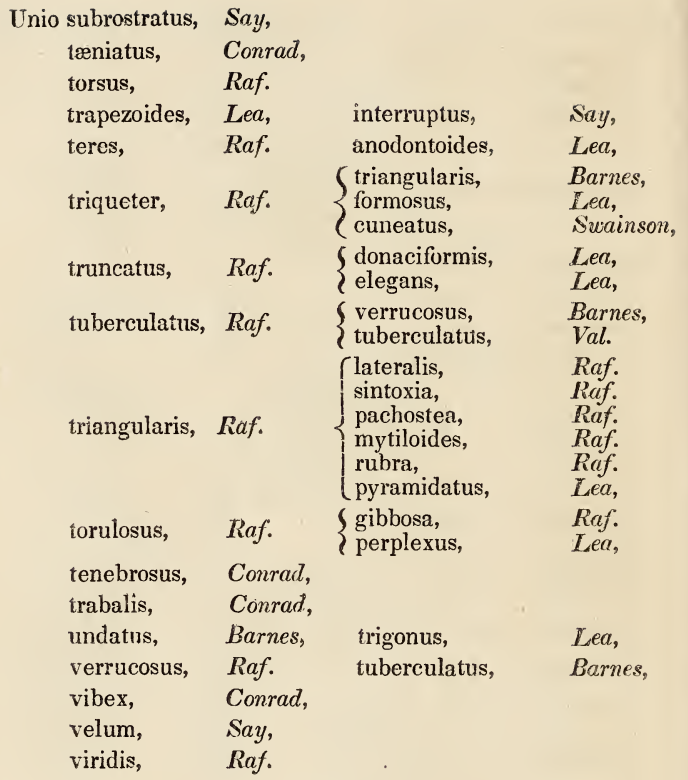

A L A S M ODONTA.

$\begin{array}{ccc}\begin{array}{c}\text { Alasmodonta costata,Raf. } \\ \text { complanata, Barnes, }\end{array} & \begin{array}{c}\text { rugosa, } \\ \text { Symphynota com- } \\ \text { planata, }\end{array} & \text { Larnes, } \\ \begin{array}{l}\text { confragosa, Say, } \\ \text { edentula, Say, } \\ \text { marginata, Say, }\end{array} & & \\ \text { margaritifera, } & \text { scriptum, } & \text { Raf. } \\ \text { Unio margaritifera, Lam. } & \text { Llasmodon. arcuata, Barnes, }\end{array}$


Alasmodonta radiata, Conrad, sculptilis, Say, truncata, Say, Unio calceolus, Lea, undulata, Say,

\section{A NODONTA.}

Anodonta cataracta, Say, marginata, Say, declivis, Conrad, grandis, Say, implicata, $S_{t} y$, imbecillis,Say, inflata, Say, lugubris, Say, subvexa, Conrad, suborbiculata, Say, undulata, Say, rugosa, Swainson.

\section{O B S ER VATION.}

I stated that a variety of Unio declivis, $\mathrm{S}_{\mathrm{AY}}$, had been found in East Florida, but I have since ascertained that it is a distinct species. 

76

\begin{tabular}{|c|c|c|c|c|c|c|c|c|c|}
\hline & & & & & & & Page & plate & fig. \\
\hline Anodonta teres, & - & - & - & - & . & - & 47 & 7 & 2 \\
\hline Paludina genicula, & 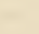 & - & - & - & . & & 48 & 8 & \\
\hline magnifica, & & - & - & - & . & - & 48 & 8 & \\
\hline Melania excurata, & & - & - & - & - & & 49 & 4 & \\
\hline Hydeii, & - & - & $=$ & - & & - & 50 & 8 & \\
\hline annulifera, & & & $\cdot$ & - & - & & 51 & 8 & \\
\hline salebrosa, & & - & - & - & & - & 51 & 4 & \\
\hline pyrenella, & & - & - & - & $\cdot$ & & 52 & 8 & \\
\hline bitæniata, & - & - & - & - & & - & 52 & 8 & \\
\hline comma, = & & - & - & $\cdot$ & - & & 53 & 8 & \\
\hline lima, & - & - & - & - & . & - & 54 & 8 & \\
\hline alveare, - & & - & - & - & - & & 54 & 4 & \\
\hline nassula, & - & - & - & - & & - & 55 & 8 & \\
\hline cylindracea, & & & $\cdot$ & $\cdot$ & - & & 55 & 8 & \\
\hline trochiformis, & & - & - & - & & - & 56 & 8 & \\
\hline vestita, & & - & - & - & $\cdot$ & & 57 & 8 & \\
\hline Anculotus prærosus, & & - & - & - & & - & 59 & 8 & 3 \\
\hline subglobosu & & & $\cdot$ & $\cdot$ & - & & 60 & 8 & \\
\hline angulatus, & & - & - & - & & - & 60 & 8 & 5 \\
\hline plicatus, & & - & - & $\cdot$ & - & & 61 & 8 & 18 \\
\hline monodonto & & & - & $\cdot$ & - & & 61 & 8 & 16 \\
\hline pictus, & $\cdot$ & - & - & - & & - & 62 & & \\
\hline pumilus, & & - & & - & & - & 62 & & \\
\hline tæniatus, & & & $\cdot$ & - & - & & 63 & & \\
\hline melanoides & & - & - & - & & - & 64 & 8 & \\
\hline nigrescens & & & $\cdot$ & - & - & & 64 & 8 & 17 \\
\hline Ancylus filosus, & - & - & - & - & & . & 57 & & \\
\hline
\end{tabular}

ERRATA.

Page 11, line 14, for is very remarkable, read are very remarkable.

Page 10, line 3 , for irridescent read iridescent. 


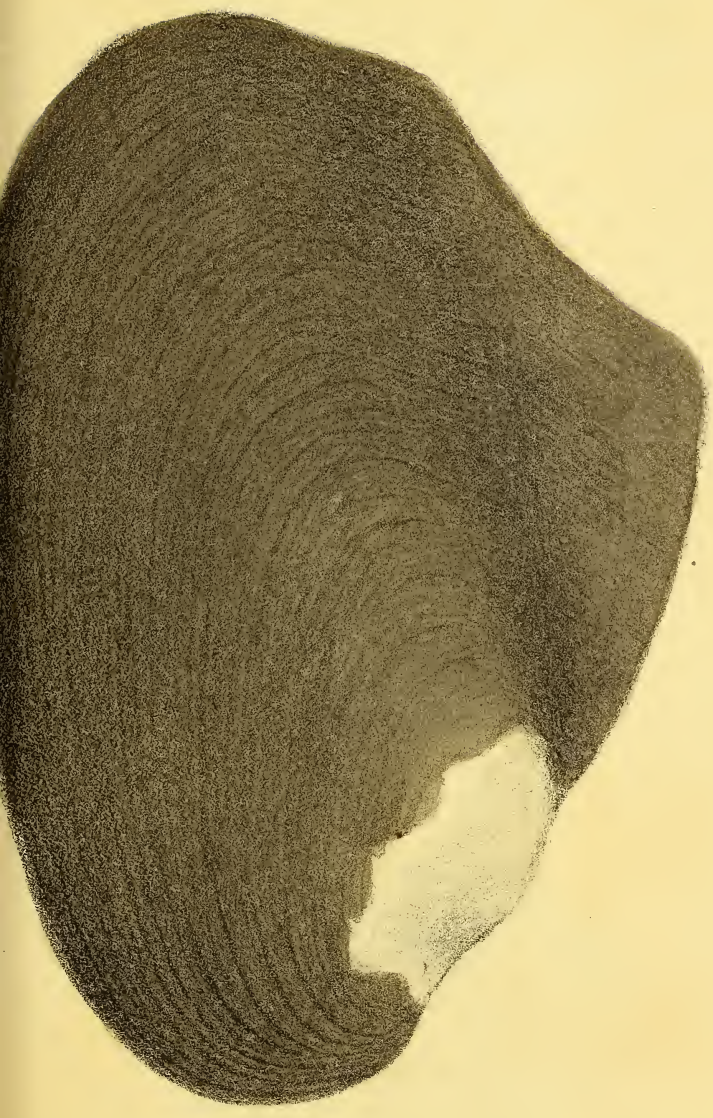




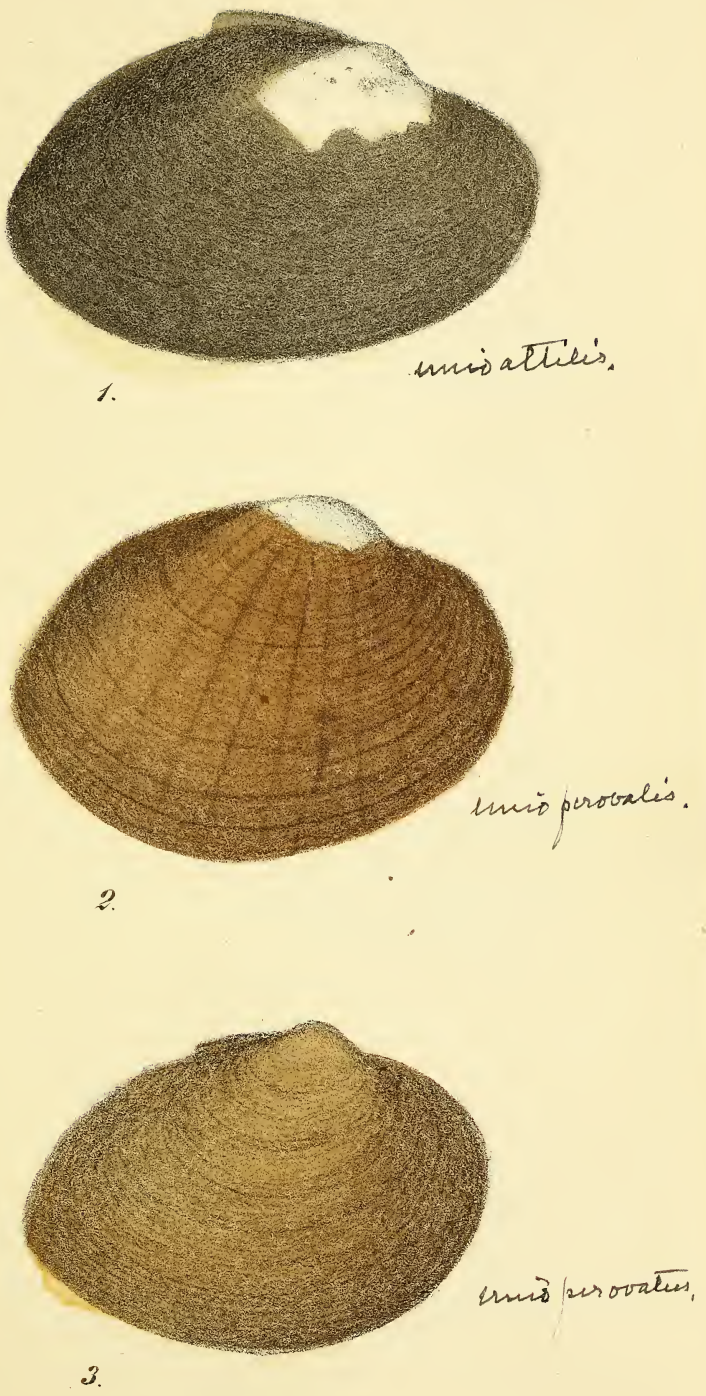

Chiths \& Lehrman Lith: 


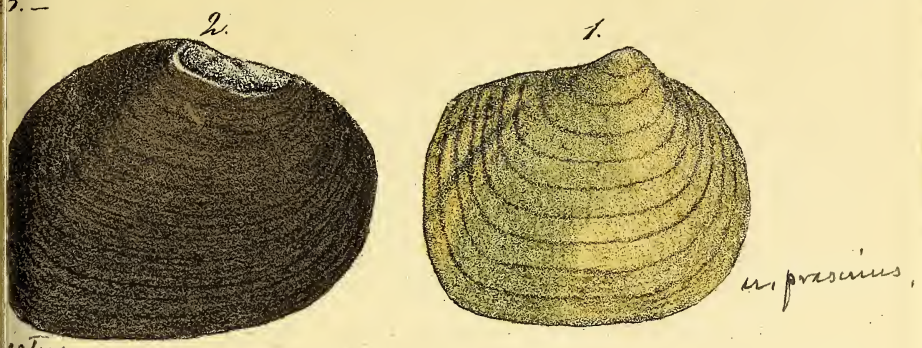
aties,

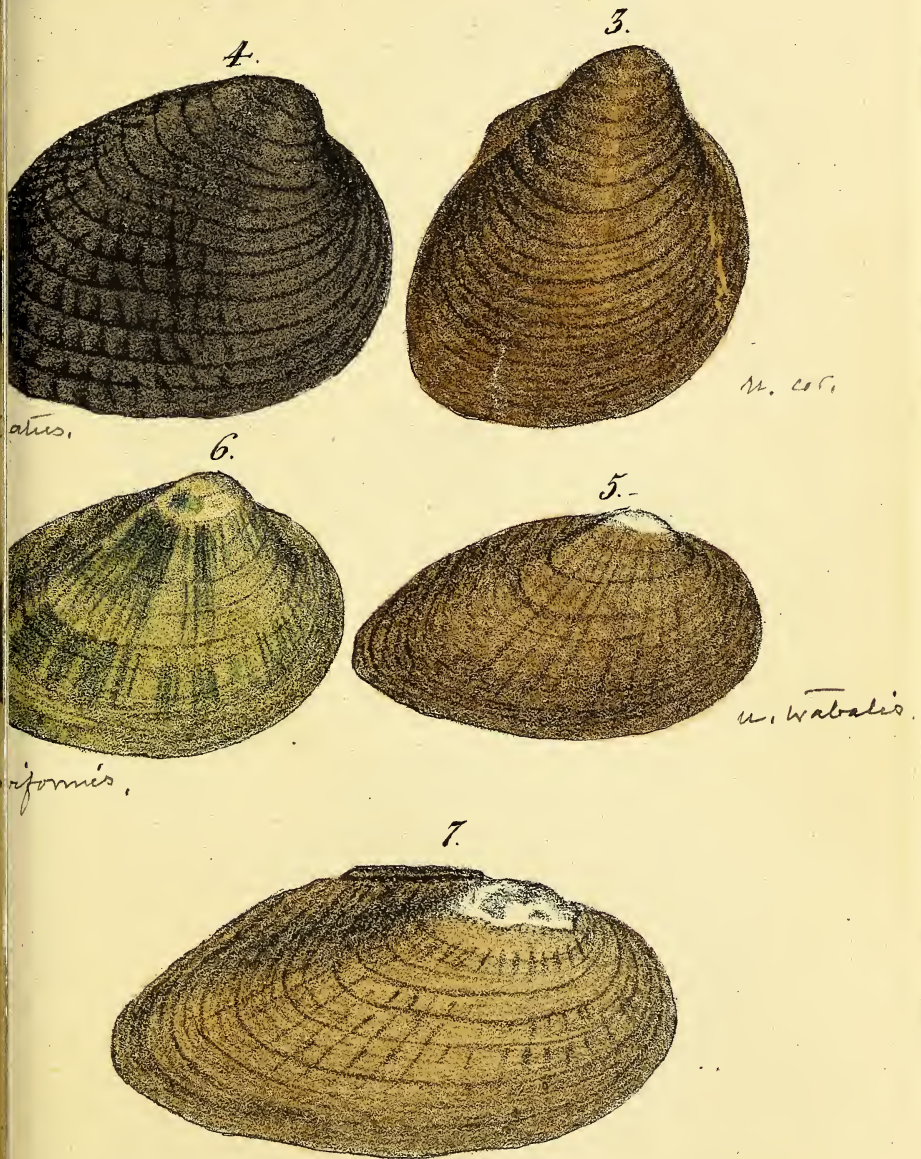

en pebstosens. 

Plate 1 .
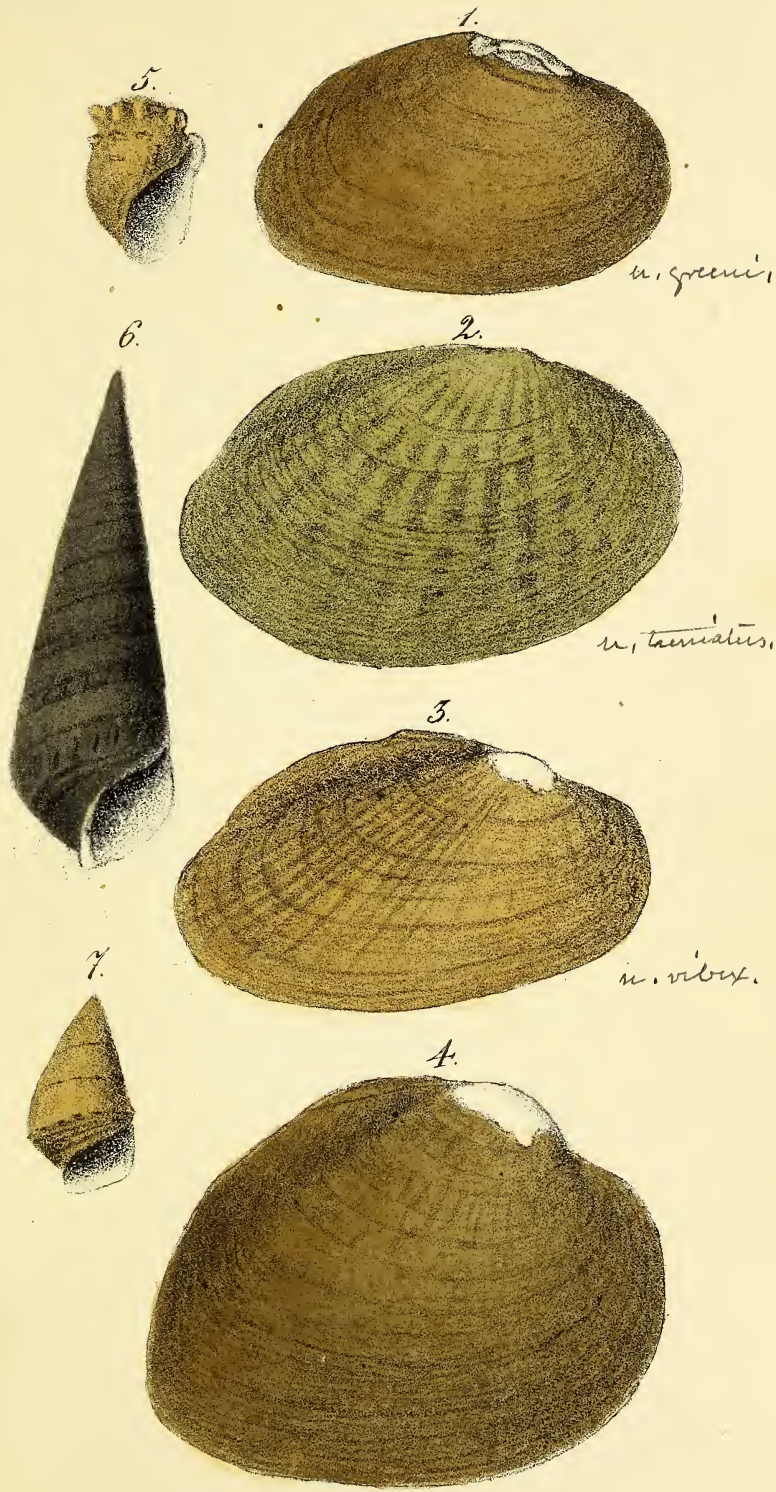

n.maculates. 

PL. 6:
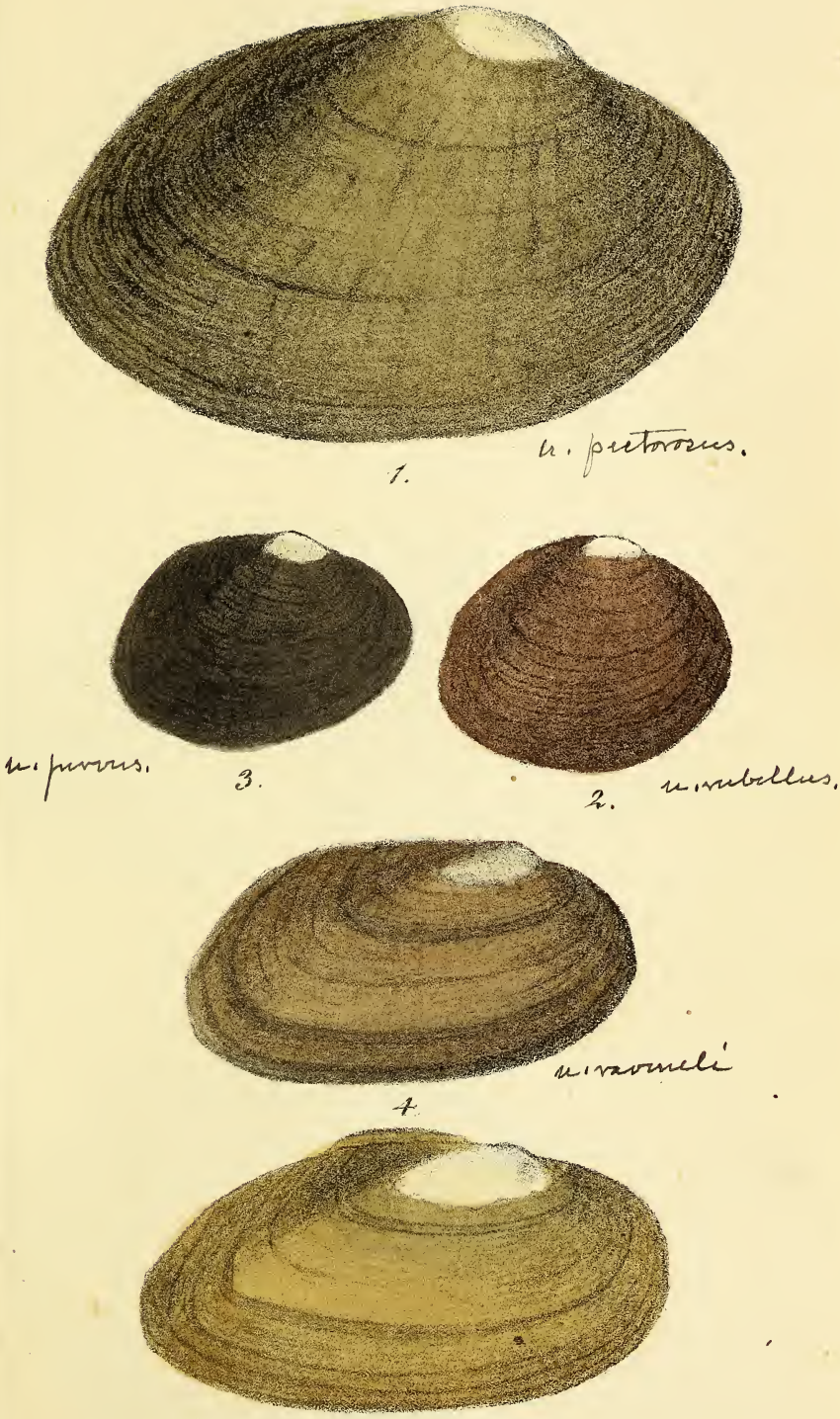

$$
\text { n. Tetrinis. }
$$





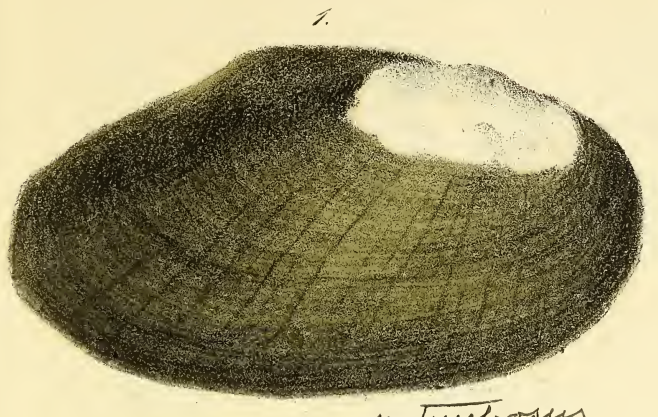

n. tonetrosus

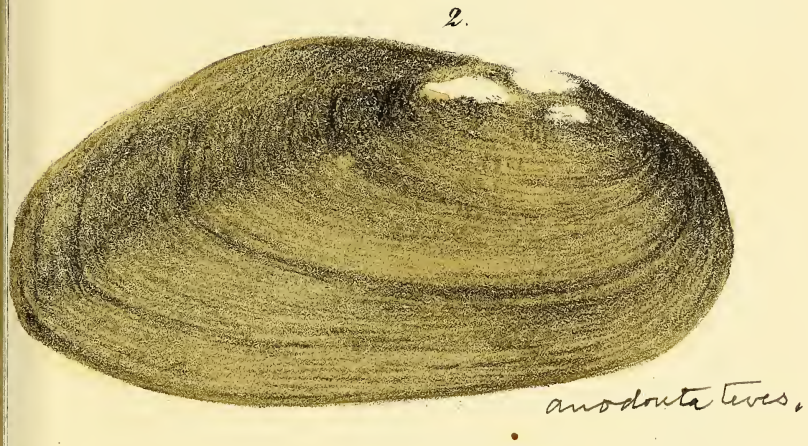

3.

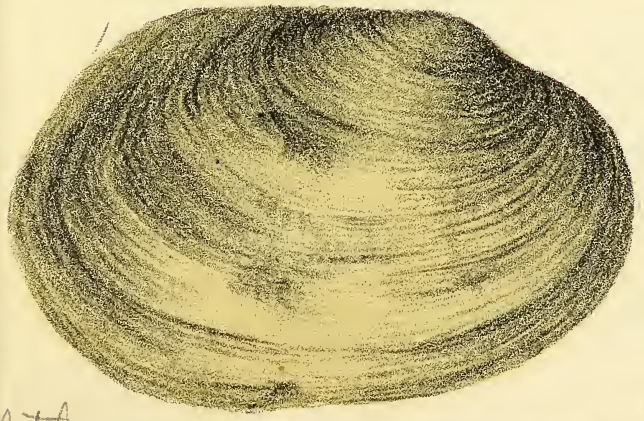

soluteta Probaber, $h$, strammens,

Brozum's Lith. 

$7=8$
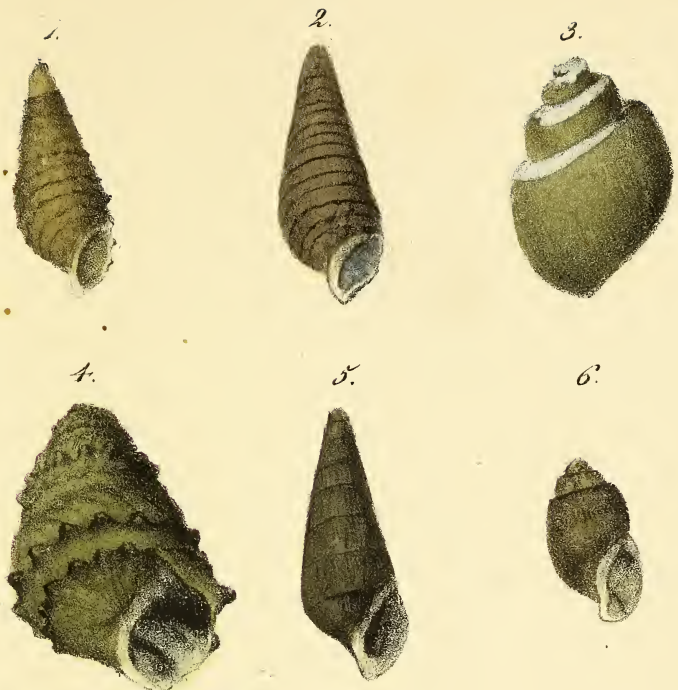

6

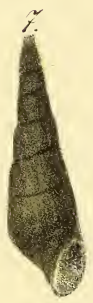

$\mathcal{S}$
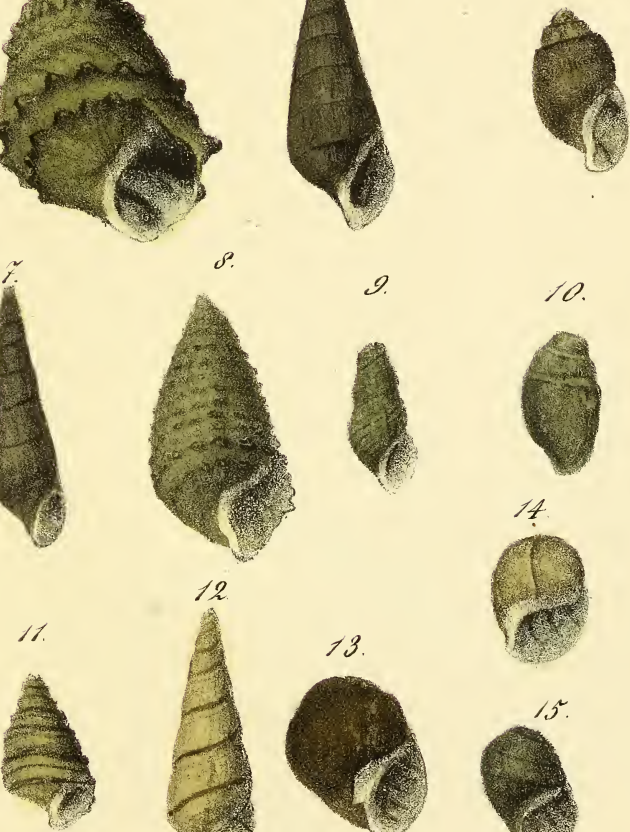

10
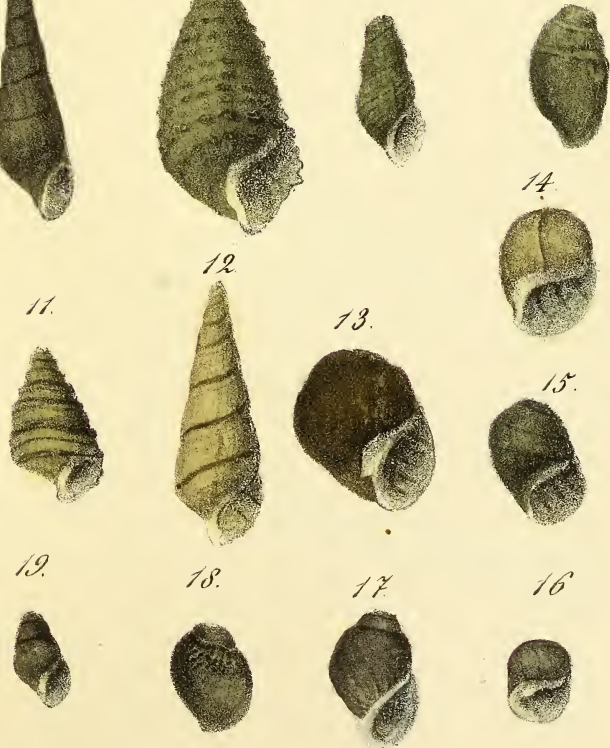

16

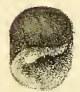




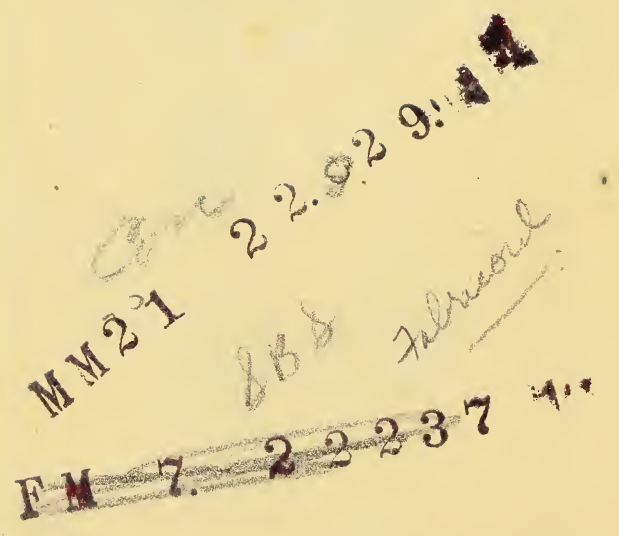






